\title{
Determinants and Costs of Current Account Reversals under Heterogeneity and Serial Correlation
}

\author{
Christian Aßmann* \\ Department of Economics, Christian-Albrechts-Universität Kiel, Germany
}

October 14, 2006

\begin{abstract}
Empirical evidence suggests that reversing current account balances imply costly adjustment processes. Recent literature analyzes the costs of adjustment processes via treatment regressions and assesses the determinants of reversals via probit models. With larger data sets becoming available, steps to control for unobserved heterogeneity within the data are necessary. This paper contributes a Bayesian analysis, which allows a flexible and efficient handling of heterogeneity and serial correlation and compares the results to those obtained by (simulated) maximum likelihood estimation. While consideration of serial correlation enables to account for the time series character of the data, random coefficients allow an efficient modeling of unobserved heterogeneity across countries. The findings suggest that an efficient consideration of serial correlation and heterogeneity is necessary to assess the determinants and the costs of a reversal correctly. Furthermore, the paper illustrates the dependency of the results on the underlying reversal definition and shows that the costs of a reversal in terms of economic growth are overestimated for some reversal definitions, when heterogeneity and serial correlation are neglected. Bayesian and maximum likelihood based specifications tests provide evidence in favor of models incorporating heterogeneity and correlation.
\end{abstract}

JEL classification: C30; F32; F43

Keywords: Current account reversals; Bayesian Analysis; Panel Probit Model; Panel Treatment Model; Random Parameters; Serial Correlation

\footnotetext{
${ }^{*}$ Corresponding address: Tel.: +49-431-8803399; fax: +49-431-8807605. E-mail: christian.assmann@statecon.uni-kiel.de (C. Aßmann)
} 


\section{Introduction}

The evidence of costly current account adjustment processes succeeding changes in the world capital movements has been analyzed by several authors. Beside studies being concerned with explaining current account phenomena on a national level, see e.g. Calvo and Mendoza (1996), Cashin and McDermott (1996), Calvo et al. (2003) and Ansari (2004), other authors as Frankel and Rose (1996) and Hutchinson and Neuberger (2001) analyze the impacts of readjustments of current account deficits for the group of emerging countries. Also region specific groups such as East Asian and Latin American countries as well as the countries in Central and Eastern Europe have been analyzed, see e.g. Milesi-Ferretti and Razin (1996), Barro (2001), Calvo (2001) and Melecky (2005). Furthermore, with larger data sets becoming available, the impact of reversing current account deficits has been analyzed in the context of large country panels containing not only specific groups. Milesi-Ferretti and Razin (1998) use panel data containing mostly low and middle income countries to explain the determinants of current account reversals and their influence on economic growth. Edwards (2004) highlights the costs of current account adjustment processes utilizing panel data including industrial as well as less developed countries. As early as Haberler (1964) noted, the group of less developed countries is still more heterogenous than the group of industrial countries. While larger data sets provide more explanatory variables, they ask for efforts to control for the unobserved heterogeneity within. Milesi-Ferretti and Razin (1998) provide a set of explanatory variables for current account reversals, which is less detailed with respect to institutional particularities than the group or country specific studies of for instance Barro (2001) and Calvo (2003). Explanatory variables are identified via a pooled probit analysis, which allows to assess the impact of variables and a single disruptive event. The set includes domestic variables such as openness and the level of reserves as well as external variables such as growth rates of industrial countries and US real interest rates. Determinants of current account as such have been analyzed by several authors, see e.g. Chinn and Prasad (2003). Milesi-Ferretti and Razin (1998) analyze the impact of reversals on economic growth via linear regressions, whereas Edwards (2004) applies a treatment analysis. He focusses also on the influence of financial openness taking the possible correlation between both phenomena into account.

The aim of this paper is to highlight the changes that occur in explaining reversals, when the prevailing heterogeneity is taken into consideration via a mixed probit approach as well as serial correlation structures to account for the time series character of the data and improve the estimation efficiency. Heterogeneity is modeled via random coefficients as for some countries no reversal is 
observed which would leave a fixed effects approach unidentified. Also possible changes in the relationship between current account reversals and economic growth, which stem from the incorporation of heterogeneity via random coefficients are analyzed via a treatment model. The contribution of this paper is to highlight the necessity of modeling heterogeneity efficiently via a Bayesian analysis, which allows also to asses the influence of single variables without relying on asymptotic properties on basis of the posterior distribution, which enables to account for possible skewness.

For the estimation of these modified treatment models as well as for the mixed probits a Bayesian approach based on Markov Chain Monte Carlo (MCMC) techniques is used. According to Bolduc et al. (1997), Bayesian estimation proves to be more flexible and faster in the context of mixed probit models than maximum likelihood approaches. Also it provides another framework for model testing, which in contrast to frequentistic methods does not depend on asymptotic properties. The adequacy of these specifications is tested via comparison of the marginal likelihoods of the models with and without heterogeneity in the parameters. Also, as will be shown by the study, the simulated maximum likelihood results suffer relative large estimation uncertainty, as high dimensional integration is involved in calculating the likelihood.

Further it is highlighted whether the inclusion of country specific heterogeneity improves the ability of the model to identify reversals. The robustness of the results is checked against several alternative possibilities to define the shift magnitude that triggers current account reversals. The definitions follow Alesina and Perotti (1997) who use a similar definition in the context of fiscal stabilization is concerned with a shift in the average level of current account.

The outline of the paper is as follows. Section 2 describes the data an the used variables. Also the specifics of the alternative reversal identification schemes are presented. The frameworks with and without heterogeneity of the probit and treatment model are presented in Section 3. Within this section also the used Bayesian estimation technique is described. In Section 4 the empirical findings are presented. Section 5 concludes.

\section{Data Description and Reversal Identification}

Used data is constructed out of the Worldbank World Development Indicators 2005 (WDI) and the Global Development Finance 2004 (GDF) databases. These databases provide annual data ranging from 1960-2004 for a total of 208 (WDI) and 135 (GDF) countries respectively, but only for a few variables not including current account balance before 1970. Further, not all variables of interest are 
available for each country and each year, thus resulting in an unbalanced panel with less than the possible 135 countries included. Following Milesi-Ferretti and Razin (1998), Bagnai and Manzocchi (1999) and Edwards (2004) macroeconomic as well as external and global variables are used to explain the occurrence of reversals. The following paragraphs will describe the included variables in these three categories and shortly review their meanings suggested by different theories.

Macroeconomic variables included are economic growth given as the annual growth rate of real gross domestic product (GDP), the share of investment in GDP proxied by the ratio of gross capital formation and GDP, the log GDP per capita in 1975 and final government consumption expenditures as a fraction of GDP to indicate the fiscal conditions of a country. The growth of real GDP can indicate the attractiveness for foreign investment capital, as high growth rates reflect investment opportunities what possibly leads to current account deficits. Also a high investment share could for similar reasons result in higher deficits. The log GDP per capita in 1975 is linked to the theory of stages in development economics. Higher GDP reflect a more developed economy, which more often exports capital. Government consumption is used to proxy the healthiness of the fiscal environment, which could affect the capital flows into a country.

As external variables are included the current account balance as a fraction of GDP, a terms of trade index $(2000=100)$, the share of exports and imports of goods and services in GDP as a measure of trade openness, the share of concessional debt in total debt, interest payments relative to GDP, the share of foreign exchange reserves in imports and the ratio of official transfers to GDP. In general theory suggests that high current account imbalances cannot be maintained over longer periods. Hence large deficits or surpluses may indicate a need for adjustment. Changes in the terms of trade may anticipate changes in trade flows. The opener an economy, the more it may be affected by external shocks on the one hand, but on the other hand may have more possibilities to balance domestic shocks. As concessional debt is often granted by institutional lenders below market conditions it may provide a source of stabilization for the current account balance. The same argument is valid for granted official transfers relative to GDP. But, as these two variables are subject to political decision they may as well trigger sharp adjustment processes. Interest payments relative to GDP and foreign exchange reserves are included in order to indicate the liabilities a country may have to serve.

Global variables taken from the databases are the US real interest rates and the real growth rates of the OECD countries. These two variables shall reflect the state of the world economy and the implied influences of current account readjustments. Rising interest rates may cause higher costs of 
credits for some countries and therefore lead to current account adjustment. Also a country may attract less investments from abroad. A high growth of the merely industrial OECD countries can for example lead to increasing demand for commodities, which may help to reduce some countries deficits.

A panel consisting out of 963 observations from 60 countries, when all these variables are taken into account, remains. Furthermore a country has to provide at least 10 observations to be included into the panel. ${ }^{1}$ The number of observation per country does furthermore not exceed 22 periods, since some variables are only available from 1980 onwards.

Current account reversals are defined using several ad hoc criteria. Identifying reversals is therefore not data driven as proposed by (3). To attenuate the effect of this ad hoc approach different definitions of current account reversals are considered, four in total. Identification schemes $(I-I V)$ are characterized as changes in the average level of current account balance, which is in line with Alesina and Perrotti (1997). According to scheme (I) a reversal episode in period $t$ is given when the current account balance in $t$ is indeed a deficit and the average current account deficit $t$ to $t+2$ compared to the average current balance over periods $t-3$ to $t-1$ is reduced by at least $3 \%$. A further restriction is that for a positive reversal the deficit level after the reversal does not exceed $10 \%$. In order to measure a sustainable reduction in current account deficit a reversal is classified in period $t$ only, when the maximum deficit after the reversal is below the minimum deficit before the reversal.

To avoid that the same reduction shows up twice in the averages, reversal scheme $(I I)$ allows no further reversal to happen in the two consecutive years after a reversal. Scheme $(I I I / I V)$ differ from scheme $(I / I I)$ only with respect to the shift magnitude of average current account balance triggering a reversal, which has to exceed now $5 \%$. The number of reversals identified under the alternative identification schemes are reported in Table (1). Entries on the main diagonal provide the number of identified reversals for the four alternative schemes, where as the other entries provide the number of reversals which are jointly identified by alternative schemes. In total data summarizes 1312 time periods, as three year averages are considered. When all identifications schemes are

\footnotetext{
${ }^{1}$ The following list of countries are analyzed: Argentina, Bangladesh, Benin, Bolivia, Botswana, Brazil, Burkina Faso, Burundi, Cameroon, Central African Republic, Chile, China, Colombia, Congo. Rep., Costa Rica, Cote d'Ivoire, Dominican Republic, Ecuador, Egypt. Arab Rep., El Salvador, Gabon, Gambia. The, Ghana, Guatemala, GuineaBissau, Haiti, Honduras, Hungary, India, Indonesia, Jordan, Kenya, Lesotho, Madagascar, Malawi, Malaysia, Mali, Mauritania, Mexico, Morocco, Niger, Nigeria, Pakistan, Panama, Paraguay, Peru, Philippines, Rwanda, Senegal, Seychelles, Sierra Leone, Sri Lanka, Swaziland, Thailand, Togo, Tunisia, Turkey, Uruguay, Venezuela. RB, Zimbabwe.
} 
applied simultaneously only 53 reversals are identified from a maximum number of 127 reversals under scheme $I$. Given these features of the different identification schemes, they are all used to yield access to the determinants and effect of current account reversals.

\section{Model Description and Model Estimation}

Within this section the empirical models are introduced, which are used to analyze the determinants of current account reversals and the impact of a reversing current account on the growth process. The specified models allow for country specific heterogeneity and/or serially correlated error terms in order to account for the characteristics of the used panel data. Also, the methods to compare the different specifications are introduced.

\subsection{Probit Model}

The determinants of the model are analyzed via probit regressions. This allows to asses the influence of a large set of explanatory regressors proposed in the literature on the occurrence probability of a reversal. Starting point is the pooled panel probit model given as

$$
\delta_{i t}= \begin{cases}1, & \text { if } \delta_{i t}^{*} \geq 0 \\ 0, & \text { if } \delta_{i t}^{*}<0\end{cases}
$$

where $\delta_{i t}$ indicates the occurrence of a reversal identified under the different identification schemes. The latent process $\delta_{i t}^{*}$ linking the explanatory variables to the reversal is assumed to follow a linear process

$$
\delta_{i t}^{*}=X_{i t} \beta+e_{i t},
$$

where $e_{i t}$ is an iid error term. If latent variable $\delta_{i t}^{*}$ raises above zero, then a reversals is indicated.

Country specific heterogeneity is incorporated into the model as follows. The parameter vector $\beta$ is assumed to become an iid country specific random variable with the same mean and covariance matrix, i.e.

$$
\beta_{i} \stackrel{\text { iid }}{\sim} \mathcal{N}\left(b, W_{b}\right)
$$

where $W_{b}$ denotes the covariance matrix of the random coefficients. Note that $W_{b}$ can also be diagonal assuming independence of the random coefficients. This random coefficient approach incorporates also a form of serial correlation. An approach via fixed effects is not possible for this data set, as not 
all countries experience a reversal, therefore not allowing country specific parameters. $\beta_{i}$ thereby reflects the country specific influence a variable has on the occurrence probability of a reversal. Via using random coefficients a general form of country specific heterogeneity is allowed, which possibly highlights, whether countries a priori considered to exhibit common characteristics show comparable behavior, or not. The mean vector $b$ provides insight into the relationship between determinants and reversals abstracting from heterogeneity. Furthermore, one can incorporate the case that not all parameters are randomized. The altered model is given by

$$
\delta_{i t}^{*}=\bar{\beta} X_{i t}+\beta_{i} X_{i t}^{\mathrm{ran}}+e_{i t},
$$

where superscript ran refers to the variables assigned a random coefficient. Hence, the probability of a country $I$ being at time $t$ in the observed state $\delta_{i t}$ conditional on $\beta_{i}, \bar{\beta}$ is

$$
P_{i t \mid \beta_{i}, \bar{\beta}}=\Phi\left(\left(2 \delta_{i t}-1\right)\left(\bar{\beta} X_{i t}+\beta_{i} X_{i t}^{\mathrm{ran}}\right)\right)
$$

where $\Phi(\cdot)$ is the the standard normal distribution. Given the probabilities $P_{i t \mid \beta_{i}, \bar{\beta}}$ the likelihood is given as

$$
L\left(\left\{X_{i t}, \delta_{i t}\right\} \mid \bar{\beta}, b, W_{b}\right)=\prod_{i=1}^{N} \int_{\beta_{i}}\left(\prod_{t=S(i)}^{T(i)} P_{i t \mid \bar{\beta}, \beta_{i}}\right) f\left(\beta_{i} \mid b, W_{b}\right) d \beta_{i},
$$

where $S(i)$ denotes the first and $T(i)$ the last available period for country $i$.

Serial correlation can be introduced in two forms. On the one hand, serial correlation can be introduced via the error components of the latent model, on the other hand lagged values of the latent $\delta_{i t}^{*}$ can be included as explanatory variables. In both forms estimation is conditional on presample information. Using the error structure to model serial correlation, the implicit condition is $\epsilon_{0}=0$, i.e. no error is observed in the pre-sample period. When values of the lagged dependent variable are used, the same condition arises, when the set of explanatory variables is available for the pre sample periods, i.e. when $\delta_{i 0}^{*}=X_{i 0} \beta_{i}$. As for some countries, the number of observed time periods do not exceed 10, no data is assigned to provide pre sample information. Incorporating serial correlation within the error structure is hence modeled as an autocorrelated error process of the form

$$
e_{i t}=\rho_{1} e_{i t-1}+\ldots+\rho_{l} e_{i t-l}+u_{i t}
$$

where $u_{i t}$ is a normal white noise $(0,1)$ process and Thus, the vector of all errors for country $i$ are jointly normal distributed. The covariance matrix of an individual when the lag order is for instance 
1 is given as

$$
\Omega=\left\{\omega_{h j}\right\}, \quad h, j:\{T(i)-S(i)+1 \times T(i)-S(i)+1\}, \quad \omega_{h j}=\frac{\rho^{|h-j|}}{1-\rho^{2}} .
$$

Denoting the vector of occurrence probabilities for country $i$ as $P_{i}$. conditional on the random coefficients $\beta_{i}$, this probability is given as the integral expression

$$
P_{i}=\int_{d\left(\delta_{i S(i)}, X_{i S(i)}, \bar{\beta}, \beta_{i}\right)} \cdots \int_{d\left(\delta_{i T(i)}, X_{i T(i)}, \bar{\beta}, \beta_{i}\right)} \Psi\left(e_{i S(i)}, \ldots, e_{i T(i)}\right) d e_{i S(i)} \ldots d e_{i T(i)},
$$

where $\Psi$ denotes a multivariate density with mean vector zero and covariance $\Omega$ and $d\left(\delta_{i t}, X_{i t}, \bar{\beta}, \beta_{i}\right)$ denote the corresponding range for integration. This results in the likelihood given as

$$
L\left(\left\{X_{i t}, \delta_{i t}\right\} \mid \bar{\beta}, b, W_{b}, \rho\right)=\prod_{i=1}^{N} \int_{\beta_{i}} P_{i} . f\left(\beta_{i} \mid b, W_{b}\right) d \beta_{i} .
$$

Estimation of these models is possible via a simulated maximum likelihood approach or a Bayesian approach. Here a Bayesian approach is considered as it allows a faster and more flexible handling of the discussed model features. The high dimensionality provides another argument in favor of MCMC methods, as they are well suited for high dimensional integration. In a Bayesian setup the posterior is hence proportional to

$$
p\left(\bar{\beta}, b, W_{b}, \rho \mid\left\{X_{i t}, \delta_{i t}\right\}\right) \propto L\left(\left\{X_{i t}, \delta_{i t}\right\} \mid \bar{\beta}, b, W_{b}, \rho\right) \pi\left(\bar{\beta}, b, W_{b}, \rho\right),
$$

where $\pi\left(\bar{\beta}, b, W_{b}, \rho\right)$ denotes the conjugate prior The implemented prior distributions incorporate $a$ priori information into the estimation. Naturally, these information should provide no restriction on the possible sphere of estimation. Unfortunately, the prior variances in a Bayesian setup especially in relatively small sample have to specified cautiously as they may cause instability, when large realization occur during the Gibbs run. In small to middle sized samples the information provided by the prior has to take into account the dimension in which the estimator will possible realize. Therefore variance priors are specified under consideration of the pooled estimates. The priors of $\bar{\beta}$, $b, W_{b}$ and $\rho$ are assumed to be mutual independent and non-informative. Hence $\pi(\bar{\beta})$ and $\pi(b)$ are multivariate normal with mean zero and a variance of 10 for each element. $\pi\left(W_{b}\right)$ is either Inverted Wishart distributed when the random coefficients are mutually independent, or the product Inverted gamma distributions. In both cases a non informative prior is assigned. The prior for the parameters of the autoregressive error structure is a multivariate normal with zero mean and variance equal to 1 for each element. 
The implemented Gibbs sampler generates draws from the the joint posterior of the models via iteratively sampling from the set of full conditional distributions. The algorithm has the following structure:

(i) Simulate from $f_{i}\left(\left\{e_{i t}\right\}_{t=S(i)}^{T_{i}} \mid \bar{\beta}, \beta_{i},\left\{X_{i t}, \delta_{i t}\right\}_{t=1}^{T_{i}}, \rho\right) i: 1 \rightarrow N$, which is a multivariate truncated normal. When serial correlation is modeled via the error structure the algorithm of Geweke (1989)is used, where draws from the joint distribution of errors are obtained via iterative draws from the set of full conditionals, which are in fact univariate truncated normals incorporating the restrictions $e_{i t}>-X_{i t} \beta_{i}$ if $\delta_{i t}=1$ and $e_{i t}<-X_{i t} \beta_{i}$ if $\delta_{i t}=0$.

- Given the sequences of the error terms, simulate from $f\left(\rho_{1}, \ldots, \rho_{l} \mid\left\{\eta_{i t}\right\}\right)$, which is a multivariate normal distribution, arising from the equation $e_{i t}=\rho_{1} e_{i t-1}+\ldots+\rho_{l} e_{i t-l}+u_{i t}$.

(ii) Simulate from $f_{i}\left(\beta_{i} \mid\left\{e_{i t}\right\}_{t=S(i)}^{T_{i}},\left\{X_{i t}, \delta_{i t}^{*}\right\}_{t=1}^{T_{i}}, \bar{\beta}, \rho\right)$, which is multivariate normal distribution. Simulation is possible, since the inclusion of $\delta_{i t}^{*}$ linearizes the setup.

- Simulate from $f\left(b \mid\left\{\beta_{i}\right\}_{i=1}^{N}, W_{b}\right)$, which is multivariate normal given the trajectories $\left\{\beta_{i}\right\}_{i=1}^{N}$ and the corresponding covariance matrix $W_{b}$.

- Simulate from $f\left(W_{b} \mid\left\{\beta_{i}\right\}_{i=1}^{N}, b\right)$, which is Inverted Wishart distributed or when $W_{b}$ is diagonal, each element is Inverted Gamma.

(iii) Simulate from $f\left(\bar{\beta} \mid\left\{e_{i t}\right\}_{t=S(i)}^{T_{i}},\left\{X_{i t}, \delta_{i t}^{*}\right\}_{t=1}^{T_{i}}, \beta_{i}, \rho\right)$, which is multivariate normal arising from the model $y_{i t}^{*}-\beta_{i} X_{i t}^{r a n}=\bar{\beta} X_{i t}+e_{i t}$.

For comparisons, the specifications are also estimated via simulated maximum likelihood, see e.g. Greene (2004) and Train (2003). Furthermore, modeling serial correlation within the errors allows the computation of the likelihood function using the $G H K$-simulator, which is necessary for model comparison based on Bayes factors as proposed by Chib (1995). For the panel probit model with heterogeneity and serial correlation we have the likelihood given in Equation (10). The likelihood function can therefore be evaluated via simulation. The algorithm consists out of the following steps.

(i) Simulated $M$ draws $\beta_{i}^{(m)}, m: 1 \rightarrow M$ from $f\left(\beta_{i} \mid b, W_{b}\right)$.

(ii) Conditional on one $\beta_{i}^{(m)}$ approximate $p\left(\left\{\delta_{i t}, X_{i t}\right\} \mid \bar{\beta}, \beta_{i}^{(m)}, \rho\right)$ via the $G H K$-simulator, see Geweke et al. (1994) or Börsch-Supan and Hajivassiliou (1993) for details. The simulator generates $M$ draws from the corresponding multivariate distribution. Therefore, the joint distribution of 
$e$ is split into the corresponding conditional distributions. The approximation has hence the form

$$
\hat{p}^{(m)}\left(\left\{\delta_{i t}, X_{i t}\right\} \mid \bar{\beta}, \beta_{i}^{(m)}, \rho\right)=\frac{1}{M} \sum_{m=1}^{M} \prod_{t=S(i)}^{T(i)} \xi\left(e_{t}^{(m)} \mid e_{-t}^{(m)}\right),
$$

where $\xi\left(e_{t} \mid e_{-t}\right)$ denotes the corresponding univariate truncated normal distribution, conditional on all other elements of the vector $e$ before time period $t$.

(iii) Hence the likelihood is approximated as

$$
\tilde{L}\left(\left\{X_{i t}, \delta_{i t}\right\} \mid \bar{\beta}, b, W_{b}, \rho\right)=\prod_{i=1}^{N}\left(\frac{1}{M} \sum_{m=1}^{M} \prod_{t=S(i)}^{T(i)} \xi\left(e_{t}^{(m)} \mid e_{-t}^{(m)}, \beta_{i}^{(m)}\right)\right) .
$$

Given the simulated likelihood function, a numerical optimizer can be used to obtain the likelihood estimates.

\subsection{Treatment Model}

The treatment model allows to assess the effect of and discrete event on a metric variable. It consists out of the following two equations

$$
\begin{aligned}
g r_{i t} & =Z_{i t} \alpha+\epsilon_{i t}, \\
\delta_{i t}^{*} & =X_{i t} \beta+\eta_{i t} .
\end{aligned}
$$

Within $Z_{i t}$ the binary reversal indicator $\delta_{i t}$ is included providing the effect of a reversal on growth. The set of explanatory variables in both equations contains the variables described in Section 2, where exclusionary restriction were obeyed for identification purposes.

Serial correlation is incorporated within the error terms of the probit regression. Assessing the effect of a reversal on economic growth via a treatment model allows to account explicitly for correlation between these two phenomena. Hence

$$
\eta_{i t}=\rho \eta_{i t-1}+u_{i t},
$$

and

$$
\left(\begin{array}{c}
\epsilon_{i t} \\
u_{i t}
\end{array}\right) \sim \mathcal{N}\left(\left(\begin{array}{l}
0 \\
0
\end{array}\right),\left(\begin{array}{ll}
\sigma^{2} & \psi \\
\psi & 1
\end{array}\right)\right)
$$


This form of error structure leads to correlation between past shocks of the growth equation and contemporaneous shock of the probit equation. Consideration of such correlation allows the latent process of the reversal to be linked to the history of shocks hitting the growth process, which are possible not adequately represented by the included explaining variables.

Again, also unobserved heterogeneity of countries shall be incorporated. As in the probit model this is done via random coefficients within each equation, i.e.

$$
\alpha_{i} \sim \mathcal{N}\left(a, W_{a}\right), \quad \beta_{i} \sim \mathcal{N}\left(b, W_{b}\right)
$$

Naturally not all variables has to be assigned a random coefficient. Hence the two equations are altered into

$$
\begin{aligned}
g r_{i t} & =\bar{Z}_{i t} \bar{\alpha}+Z_{i t}^{r a n} \alpha_{i}+\epsilon_{i t}, \\
\delta_{i t}^{*} & =\bar{X}_{i t} \bar{\beta}+X_{i t}^{r a n} \beta_{i}+\eta_{i t} .
\end{aligned}
$$

The corresponding Gibbs Sampler, which is employed to simulate from the joint posterior distribution of the model has the following structure:

(i) Simulate from $f_{i}\left(\left\{\eta_{i t}\right\}_{t=S(i)}^{T(i)} \mid \alpha_{i}, \beta_{i},\left\{X_{i t}, Z_{i t}, g r_{i t}, \delta_{i t}, \epsilon_{i t}\right\}_{t=S(i)}^{T(i)}, \sigma^{2}, \psi, \rho, a, W_{a}, b, W_{b}\right) i: 1 \rightarrow N$ which is similar to Step (i) described for the probit model. Nevertheless, here it is sampled from a multivariate truncated normal conditional on the observed errors $\epsilon_{i t}$ form the first equation. The parameters of the correlation structure are drawn conditional on the set of errors from normal distribution.

(ii) Simulate from $f_{i}\left(\alpha_{i}, \beta_{i} \mid\left\{X_{i t}, Z_{i t}, g r_{i t}, \delta_{i t}, \delta_{i t}^{*}\right\}_{t=S(i)}^{T(i)}, \sigma^{2}, \psi, \rho,\left\{\eta_{i t}, \epsilon_{i t}\right\}_{t=S(i)}^{T(i)}, a, W_{a}, b, W_{b}, \bar{\alpha}, \bar{\beta}\right) i$ : $1 \rightarrow N$, which is a multivariate normal distribution. The inclusion of the latent variable $\delta_{i t}^{*}$ leads to a linearized setup. Hence, the moments are as in seemingly unrelated regression framework. The corresponding conjugate prior is normal with mean zeros and variance of 100 for each single element. Given the trajectories $\left\{\alpha_{i}, \beta_{i}\right\}_{i=1}^{N}$ one can simulate the underlying hyperparameters $a, W_{a}, b, W_{b}$. The full conditional distributions of $a$ and $b$ are both multivariate normal, whereas the full conditionals of $W_{a}$ and $W_{b}$ are either Inverted Wishart, or if the random coefficients are assumed to be mutually independent, each element of the main diagonal follows an Inverted Gamma distribution.

(iii) Simulate form $f\left(\bar{\alpha}, \bar{\beta} \mid\left\{X_{i t}, Z_{i t}, g r_{i t}, \delta_{i t}, \delta_{i t}^{*}\right\}_{t=S(i)}^{T(i)}, \sigma^{2}, \psi, \rho,\left\{\eta_{i t}, \epsilon_{i t}\right\}_{t=S(i)}^{T(i)}, a, W_{a}, b, W_{b},\left\{\alpha, \beta_{i}\right\}_{i=1}^{N}\right)$, which is multivariate normal arising from a panel model. The corresponding conjugate prior is normal with mean zeros and variance of 100 for each single element. 
(iv) A difficulty arises in drawing the covariance matrix of the errors from an Inverted Wishart distribution, when the first element of the main diagonal $\sigma_{22}$ is normalized to 1 . The full conditional distribution has to be based on an appropriate prior incorporating this normalizing constraint. This problem has been addressed in several ways, see McCulloch and Rossi (1994), Nobile (2000) and McCulloch et al. (2000). Here, an identified prior is used, as suggested by McCulloch et al. (2000), although for medium large problems empirical experience suggest viability also for a non identified prior scheme, which would allow direct sampling from a Wishart distribution but no accurate calculation of the marginal likelihood. Simulation of $\sigma^{2}$ and $\psi$ is done using a reparametrization of the covariance of $\epsilon_{i t}$ and $u_{i t}$ given as

$$
\left(\begin{array}{cc}
\sigma^{2} & \psi \\
\psi & 1
\end{array}\right)=\left(\begin{array}{cc}
\xi+\psi^{2} & \psi \\
\psi & 1
\end{array}\right) .
$$

$\xi$ denotes the conditional part of the variance of $\epsilon_{i t}$ and can be sampled from an Inverse Gamma distribution. Draws of the covariance are obtained via setting up the linear regression $\epsilon_{i t}=\psi u_{i t}+\zeta_{i t}$, where $\zeta_{i t}$ denotes an error term with variance $\xi$. Hence, sampling $\psi$ is possible form a normal distribution with normal conjugate prior. ${ }^{2}$

In order to conduct a full Bayesian analysis, an estimate of the likelihood has to be calculated. The likelihood contribution of country $i$ can be represented as

$$
L_{i}\left(\cdot \mid a, b, W_{a}, W_{b}, \sigma, \psi, \rho, \bar{\alpha}, \bar{\beta}\right)=\int_{\alpha_{i}} \int_{\beta_{i}} \Psi_{1}(\cdot) \int \ldots \int \Psi_{2 \mid 1}(\cdot) d \epsilon_{i S(i)} \ldots \epsilon_{i T(i)} f\left(\alpha_{i}, \beta_{i}\right) d \alpha_{i} d \beta_{i} .
$$

$\Phi_{1}(\cdot)$ denotes the the marginal distribution of $\epsilon_{i}$. evaluated at $g r_{i .}-Z_{i .} \alpha_{i}$ and $\Phi_{2 \mid 1}(\cdot)$ the conditional distribution of $\eta_{i .} \mid \epsilon_{i}$. with corresponding conditional mean and conditional variance. The integral over the multivariate distribution is evaluated using the $G H K$-simulator. The random coefficients are integrated out via averaging the likelihood conditional on draws form the marginal distributions of $\alpha_{i}$ and $\beta_{i}$.

\subsection{Model Comparison}

The Bayesian framework allows to compare the different specifications via the marginal likelihood $m(S)$, which gives the evidenc of sample data $S$ under a specific model. This concept incorporates the parameter uncertainty and allows a consistent model assessment even for smaller samples as it is not based on asymptotic properties. The derivation of the marginal likelihood is along the way

\footnotetext{
${ }^{2}$ Further details are given in McCulloch et al. (2000).
} 
proposed by Chib (1995). A more general introduction is provided by Kass and Raftery (1995). Starting point of the derivation is to decompose the marginal likelihood into

$$
\ln m(S)=\ln l\left(\theta^{*} \mid S\right)+\ln \pi\left(\theta^{*}\right)-\ln p\left(\theta^{*} \mid S\right)
$$

As this identity holds for all $\theta$, it is calculated within a high density region. The first component gives the log likelihood. For the pooled panel probit and treatment it is given via a closed form. For the specification allowing for serial correlation and/or heterogeneity, the likelihood is computed using simulation techniques as the $G H K$ simulator described above. The second component is the log prior of all model parameters. The last component of the marginal likelihood is the full posterior distribution of $\theta=\left(\theta_{1}, \theta_{2}, \ldots\right)$, where $\theta_{i}$ denotes a block of model parameters sampled together. The full posterior is obtained via decomposing the posterior distribution into

$$
p\left(\theta^{*} \mid S\right)=p\left(\theta_{1}^{*} \mid S\right) \cdot p\left(\theta_{2}^{*} \mid \theta_{1}^{*}, S\right) \cdot \ldots
$$

For the pooled panel probit model the full posterior distribution is provided by the Gibbs output, as only one block of parameters is present, i.e.

$$
\tilde{p}(\beta \mid S)=\frac{1}{M} \sum_{i=1}^{M} f\left(\beta^{*} \mid y^{*^{(i)}}, S\right),
$$

where $f(\cdot)$ denotes the full conditional distribution of $\beta$ and $y^{*^{(i)}}$ denote the draws of the latent variable. Also in case of random coefficients only, the estimate of the posterior is directly provided by the Gibbs output, given as

$$
\tilde{p}(\beta \mid S)=\frac{1}{M} \sum_{i=1}^{M} f\left(\beta^{*} \mid y^{*^{(i)}}, \alpha^{(i)}, S\right),
$$

with $\alpha^{(i)}$ denoting the random coefficients.

In case of serial correlation a further (shortened) Gibbs run has to be performed in order to obtain $p\left(\rho^{*} \mid \beta^{*}, S\right)$. The shortened Gibbs run is performed conditional on $\beta^{*}$. For the treatment specifications, the same specifications can be applied. Given the log marginal likelihood, model comparison is conducted using the scale of Jeffrey's (1962), which classifies the log Bayes factor as the difference between two marginal likelihoods. ${ }^{3}$

\footnotetext{
${ }^{3}$ If $B<0$ no evidence for the specification under $H_{0}$, for $0 \leq B<1.15$ very slight evidence in favor of $H_{0}$ is found, with $1.15 \leq B<2.3$ the evidence is slight, strong evidence is found for $2.3 \leq B<4.6$ and very strong evidence is found for $B \geq 4.6$.
} 
Furthermore, the different probit specifications are assessed according to their ability to indicate a reversal. The ability to indicate a reversal is given, when the conditional probability

$$
P\left(\delta_{i t}=1 \mid X_{i t} \beta_{(i)}\right) \geq 0.5
$$

exceeds 0.5. The ratio of correct and misclassified reversals serves as a model selection criterion. Note that all explaining variables $X_{i t}$ provide only information up to period $t-1$. Hence, this probability points in the direction of forecasting a reversal. Within the Bayesian framework, country specific random coefficients are given as a byproduct of the Gibbs output. The examined probability is hence the forecast of a reversal based on the posterior distribution.

\section{Empirical Results}

Within this section the estimation results reflecting the consequences of accounting for heterogeneity across countries and serial correlation on determinants and growth impact of reversals are presented. In order to highlight the influence of serial correlation and heterogeneity the robustness of findings is checked for different reversal identification schemes. Furthermore results are reviewed for Bayesian as well as simulated maximum likelihood estimation in order to check whether differences occur between the two estimation methods.

\subsection{Determinants of Current Account Reversals}

The estimates for four Probit specifications incorporating serial correlation and heterogeneity at different degrees will be discussed. Starting point is the pooled panel probit model given in Equations (1) and (2). The next specification accounts for serial correlation as in Equation (7). Afterwards, no serial correlation in the errors, but random coefficients modeling country specific heterogeneity are considered. Finally a specification incorporating both serial correlation in the error and random coefficients is estimated.

Table (2) and (9) report the results for the pooled panel specification acquired by Bayesian and Maximum Likelihood estimation respectively. Across all reversal definitions and for both estimation techniques, the terms of trade and the lagged average current account ratio are found to exercise negative influence on the occurrence probability of a reversal. The terms of trade index level illustrates the ability of a country to raise export revenues, while the higher the current account level is, the less need arises for an adjustment. A significant influence of the global variables, US real interest rate and the OECD growth is found only under the first identification scheme. This result is similar 
to Falcetti and Tudela (2006), where the influence of the global interest rates is also depending on the used definition of a crises.

The trade openness and the ratio of investment to GDP are found to be insignificant over all identification schemes and estimation methodologies, what is in line with varying results in the empirical literature, see e.g. Chinn and Prasad (2003).

Also the lagged mean growth rate and the interest payments seem to have no influence on occurrence probability of a current account reversal.Nevertheless, Bayesian estimation reveals for both coefficients that the $10 \%$ quantile of the posterior is positive in reversal scheme $I I I$, where no reversal is allowed in the two years succeeding a reversal.

Another import determinant of current account reversals is the level of reserves as a fraction of imports. It is negative for both estimation techniques and across all reversal schemes.

The government expenditure is found to rise the probability of a reversal under all identification schemes, nevertheless being significant only for scheme $I$ and $I I$. The linkage between government expenditures and current account deficits has been analyzed several times in the context of the twin deficit hypothesis, but the evidence is not stable across the literature, see e.g. .... The ratio of concessional debt to total debt is found to lower the reversal probability, what suggests that a countries ability to gain a larger fraction of its liabilities a favorable terms functions as signal of stability making capital outflows less likely. Nevertheless a significant impact is found only for reversal schemes $I I-I V$. The level of initial GDP is found to have no significant influence on the probability of a reversal. Hence, the stage of development at the starting point of international capital liberalization in 1975 seems not among the determinants of current account reversals. The evidence of an influence of official transfers is mixed, although not significant for any regime. A negative sign is found for reversal scheme $I$ and $I I$, while negative sign prevails for scheme $I I I$ and $I V$. Both estimation procedures display the influence of the underlying reversal definition as well as the mixed evidence for the set of variables influencing the occurrence probability of a current account reversal.

The next specification accounts for serial correlation, which is present due to the time series character of the macroeconomic variables and the use of an identification scheme, which relies on moving averages of variables and implies restrictions on the aftermath of an reversal. Estimation of the model incorporating up to two lags within the error structure showed that one lag sufficiently accounts for the observed correlation. Hence only the results for the specification with one lag are presented. Bayesian estimation are given in Table (3) and Table (10) provides the SML estimates 
respectively. Similar results are provided by both estimation methodologies. Serial correlation is positive for reversal schemes, where only the dynamics of current account is restricted, while it is negative for definitions, which imply a strict restriction on the two consecutive reversals. Furthermore, the correlation is not significant for the fourth scenario, henceforth suggesting that this definition produces the smallest measurement error. Compared to the pooled specification the global variables, the US real interest rate and the OECD growth rate, are now found to be insignificant across all reversal schemes. Changes in the other variables are only minor.

The evidence in favor of serial correlation is mixed across the different reversal schemes. While strong to very strong evidence is provided by the differences of the log marginal likelihood in schemes $I$ and $I I I$, the evidence in schemes $I I$ and $I V$ is only slight. Similar conclusions can be drawn on the basis of LR-tests for the maximum likelihood estimations. While serial correlation is significantly preferred at the $99 \%$ level for scheme $I$ and $I I I$, it is only preferred at the $5 \%$ level for schemes $I I$ and $I V$. This mixed evidence is in line with the results of Falcetti and Tudela (2006), which analyzed serial correlation in the context of currency crises.

After accounting for serial correlation, the influence of country specific heterogeneity shall be assessed. Considering the low variation for within the reversal indicator (especially in definition $I I I / I V)$ only a more parsimonious form of heterogeneity is assessed, where not all parameters are modeled as random coefficients. In particular random coefficients are assigned to the level of mean current account deficit, the level of concessional debt and the ratio of official transfers. These three variables bear significant heterogeneity. The Bayesian estimates are given in Table (4) and the SML estimates are given in Table (11). The OECD growth rate is found to exhibit no significant influence for reversal scheme $I$ as in the pooled specification. This might be a result of the random coefficients approach, which induces a form of serial correlation. The heterogeneity connected to the mean level of current account deficit accounts for the fact that some countries are able to maintain a higher deficit over a considerable period of time without facing a risen adjustment pressure. Nevertheless, the estimated mean effect is substantially higher than in the pooled and serial correlation specification stressing the importance of the current account balance.

Furthermore, Bayesian estimation allows to access the form of country specific heterogeneity. Figure (1) shows the distribution of the sampled country specific coefficient for the mean CAD level, concessional debt and official transfers for a small group of countries (upper panel) and for all panel members (lower panel). Especially, the influence of the mean current account on the occurrence of a probability differs between countries. For instance, the influence of the current account deficit 
is not significant for Congo, i.e. this country departs from normal economic behavior present in most countries. Differences in the impact of current account deficits on the probability of a reversal may be due to the different institutional frameworks, which are not accounted for by observable variables. Country specific heterogeneity furthermore improves the models ability to detect the observed reversals. Table (16) gives the number of identified reversal under the four considered model specifications. The ratio of correct classified cases ranges from 0.890 for the pooled model in reversal scheme $I$ to 0.913 for the model allowing for partial heterogeneity, whereby the number of of correctly identified reversal is almost doubled. For reversal scheme III the increase within the number of identified reversal is the highest. Specification tests prefer heterogeneity modeled via random coefficients across all reversal schemes. While the non nested specification allowing for serial correlation and partial heterogeneity cannot be compared directly via a LR-test, a comparison via the marginal likelihood is possible and reveals that the heterogenous specification is to be preferred strongly for reversal scheme $I-I I I$ but only mildly for reversal scheme $I V$.

Finally the Bayesian estimation results for the specification accounting for serial correlation and country specific heterogeneity and serial correlation can be found in Table (5). For the SML estimation, the results can be found in Table (12). Only a parsimonious model is estimated in order to show that only few variables are needed to identify the actually observed reversals. Also this parsimonious specification performs better than the richer pooled specifications across all reversal schemes and also better as the specification allowing for serial correlation under scheme $I$ and II. As Table (16) shows, the parsimonious specification performs comparable to the more enriched specification allowing heterogeneity in three parameters in identifying the observed reversals. The estimated serial correlation follows again the pattern being positive for reversal scheme $I$ and $I I I$ and negative for scheme $I I$ and $I V$. With respect to the other included variables not qualitative changes in the parameter estimates for both estimation methodologies are found.

Summarizing, allowing heterogeneity and serial correlation affects the analysis of determinants of current account in two ways. It stresses the importance of the mean CAD level, reserves and the terms of trade and improves the models ability to indicate observed reversals.

\subsection{Costs of Reversals under Heterogeneity}

The relationship between economic growth and current account reversals and their mutual dependence is analyzed via treatment regressions in order to highlight the cost of a reversal in terms of economic growth. Firstly, the results are reviewed for a pooled specification not considering het- 
erogeneity explicitly. Afterwards, the relationship is assessed under serial correlation and finally to round up results for a specification are discussed, where random coefficients and serial correlation are incorporated.

The Maximum likelihood estimates for the pooled model specification are given in Table (13) and the Bayesian estimates are given in Table (6). For all considered reversal schemes, the correlation between the two equations is significant varying from $\approx 0.66$ in scenarios $I / I I$ to $\approx 0.41$ in scenarios $I I I / I V$. The set of explanatory variables for the probit equation is taken from the analysis of determinants of current account reversals. The joint analysis of reversals and their impact on growth also points out the importance of some more variables not stressed by the analysis of determinants alone. Using reversal definition $I$ yields significant influence of the level of official transfers, which has a stabilizing effect on current account deficits. Also the mean growth rate is found to exhibit stabilizing impact on the occurrence of the current account balance, at least in schemes $I$ and $I I I$. On the other hand, several variables, e.g. level of the terms of trade index and OECD growth rates are not found to exhibit significant influence anymore within the first two scenarios as it is observed for the pooled probit regressions. Within the growth equation several variables also considered within the probit equation function as covariates. For instance openness is considered as an explaining factor of economic growth, investment and initial GDP per capita in 1975. Only investment is found to be overall significant. Of special interest is, wether a more open economy is less severe influenced by reversal than more closed economies. While the likelihood estimates seem to support the view that trade openness reduces the cost of a reversal, significantly at least for reversal scheme III, no evidence is found across all reversal definitions among the Bayesian estimates. Although the Bayesian estimation procedure produces similar results, the cost of reversals given by the reversal dummy are lower ranging from 6.99 for the second reversal scheme to 4.56 for reversal scheme $I V$.

Summarizing the results for the pooled treatment regressions, the differences between reversal definitions as well as estimation methodology state that one is still for from having a clear empirical evidence what determines the cost of reversals. Nevertheless, the results suggest that trade openness often cited as having stabilizing effect on the macroeconomic state of an economy may not function as such a stabilizer.

Estimation results of the treatment model, where serial correlation within the probit equation is considered, are given in Table (7). Similar to the results of the probit specifications, serial correlation is significant for all reversal schemes. Changes in the estimated coefficients within the probit equation are similar to those for the probit regressions. Fewer variables function as significant determinants 
of current account reversals compared to the pooled specifications. For the growth equation the consideration of serial correlation has major impact on the estimated reversal coefficient. Over all reversal definitions the negative impact of the reversal on the contemporaneous growth rate reduces substantially. The reduction is significant according to $t$-tests for the reversal scheme $I$ for Bayesian estimation and for reversal scheme $I$ and $I I I$ for Maximum likelihood estimation. A possible explanation is arises from the idea that the occurrence of a reversal is accompanied a large (positive) unobserved shock in the probit equation, as the probit model performs quite poor in explaining observed reversals, see Table (16). As the shocks hitting the probit and growth equations are correlated, the error of the growth equation is forced upwards, although the growth is reduced within this period, hence the effect is counterbalanced more pronounced via the reversal dummy. This especially true when two reversal occur in two consecutive periods. Introduction of serial correlation allows the latent process to adopt better via cumulation of past shocks causing lower shocks in the reversal period, which are then transmitted to the growth equation. Furthermore, the correlation between the two equations albeit significant for all reversal scenarios except the second is substantially reduced as shocks seem strongly correlated over time for the probit equation and only to a smaller extent to shocks of the growth path.

The consideration of heterogeneity and serial correlation is based on a slightly more parsimonious specification of the probit equation leaving out the not significant variables. The findings with respect to costs of reversals and the correlation are between the two equations are similar to those, where serial correlation is considered. Again, estimated costs of a reversal are substantially reduced for scheme $I$ and $I I I$ and also no significant correlation can be found for these two reversal definitions. Changes with respect to the serial correlation parameter and the variables coefficients are only minor.

\section{Summary and Conclusion}

Bayesian analysis allows a flexible handling of unobserved heterogeneity and serial correlation. The necessity to model heterogeneity via random coefficients arises from the data set, where not all countries experience a reversal hence leaving a fixed effects approach unidentified. Also, the Bayesian framework allows to compare the different model specifications without relying on asymptotic properties and provides exact small sample inference accounting for parameter uncertainty. The findings suggest that incorporating country specific heterogeneity and serial correlation is essential to meat the macroeconomic character of the panel data set in order to assess the determinants and costs of reversal correctly. Results for the probit regressions indicate that the inclusion of serial correlation 
improves efficiency, as a Bayesian model comparison via the marginal likelihood an classical tests for the likelihood estimates prefer this specification over all different reversal schemes. Allowing for unobserved heterogeneity, which also implies a form of serial correlation, leads to a preferred specification with fewer variables have a significant impact on the occurrence of a reversal. The form of country specific heterogeneity given as a byproduct of the Gibbs output reveals that for some countries the probability of a reversal is not depending on the current account deficit, although the estimated mean effect is highly significant. A possible explanation is may arise from the different institutional backgrounds of the countries, which is hardly accessible via observable variables. Next, via the incorporation of heterogeneity, the models ability to indicate the observed variables is improved, quite strongly for reversal scheme $I$, but only minor for the other reversal schemes. Consideration of both, heterogeneity and serial correlation provides an more efficient estimation, but causes no qualitative changes in the determinants of current account reversals.

The treatment analysis reveals that costs in terms of of economic growth are overestimated for some reversal definitions, when heterogeneity and serial correlation are incorporated. A significant reduction in the estimated impact of a reversal on growth is found for reversal schemes which do not exclude the consecutive years from bearing a reversal. The reduction is more pronounced in specifications allowing for cumulation of shocks in the probit equation resulting in lower contemporaneous correlation between the two equations. Again, specification tests stress the importance of incorporation heterogeneity and serial correlation, which is difficult to incorporate via suitable regressors, as data is often not available at annual frequency over longer periods. As the evidence provided by the analysis is in favor of accounting for heterogeneity, further attempts should aim on linking heterogeneity to observed variables.

\section{References}

1 Alesina, A., And Perotti, R. Fiscal Adjustments in OECD countries: Composition and Macroeconomic Effects. IMF Staff Papers, 44 (1997), 210-248.

2 Ansari, M. I. Sustainability of the US Current Account Deficit: An Econometric Analysis of the Impact of Capital Inflow on Domestic Economy. Journal of Applied Economics VII, 2 (2004), 249-269.

3 Bagnai, A., And Manzocchi, S. Current-account reversals in developing countries: The role of fundamentals. Open economies review, 10 (1999), 143-163.

4 Bolduc, D., Fortin, B. And Fournier, M. Multinomial probit estimation of spatially interdependent choices: An empirical comparison of two new techniques. International Regional Science Review, 20 (1997), 77-101. 
5 Börsch-Supan, A., And Hajivassiliou, V. A. Smooth unbiased multivariate probability simulators for maximum likelihood estimation of limited dependent variable models. Journal of Econometrics 58 (1993), 247-368.

6 Calvo, G. A. Capital markets and the exchange rate with special reference to the dollarization debate in latin america. Journal of Money, Credit and Banking 33, 2 (2001), 312-334.

7 Calvo, G. A. Explaining sudden stops, growth collapse and bop crises: The case of distortionary output taxes. NBER Working Paper Series, 9864 (2003).

8 Calvo, G. A., And Mendoza, E. Mexico's balance-of-payments crisis: A chronicle of death foretold. International Finance Discussion Papers 545 (1996).

9 Calvo, G., Izquierdo, A. And Talvi, E. Sudden stops, the real exchange rate, and fiscal sustainability: Argentina's lessons. NBER Working Paper Series, 9828 (2003).

10 Cashin, P., And McDermott, C. J. Are Australia's Current Account Deficits Excessive? IMF Working Papers 96, 85 (1996).

11 Chiв, S. Marginal likelihood from the gibbs output. Journal of the American Statistical Association 90, 432 (1995), 1313-1321.

12 Chinn, M. D., And Prasad, E. S. Medium-term determinants of current accounts in industrial and developing countries: an empirical exploration. Journal of International Economics 59 (2003), 47-76.

13 Edwards, S. Financial openness, sudden stops, and current-account reversals. American Economic Review 94, 2 (2004), 59-64.

14 Falcetti, E., And Tudela, M. Modelling currency crises in emerging markets: A dynamic probit model with unobserved heterogeneity and autocorrelated errors. Oxford Bulletin of Economics and Statistics 68, 4 (2006), 445-471.

15 Geweke, J., Keane, M. And Runkle, D. Alternative computational approaches to inference and in the multinomial probit model. Review of Economics and Statistics 76 (1994), 609-632.

16 HABerler, G. Integration and growth of the world economy in historical perspective. The American Economic Review 54, 2 (1964), 1-22.

17 Hutchison, M. M., And Neuberger, I. Output costs of currency and balance of payments crises in emerging markets. University of California Santa Cruz Working Paper Series (2001).

18 Kass, R. E., And Raftery, A. E. Bayes factors. Journal of the American Statistical Association 90, 430 (June 1995), 773-795.

19 McCulloch, R., And Rossi, P. E. An exact likelihood analysis of the multinomial probit model. Journal of Econometrics (1994), 207-240. 
20 McCulloch, Robert E., Polson, Nicholas G. and Rossi, Peter E. A Bayesian analysis of the multinomial probit model with fully identified parameters. Journal of Econometrics 99 (2000), 173-193.

21 Melecky, M. The impact of current account reversals on growth in central and eastern europe. International Finance, 0502004 (2005).

22 Milesi-Ferretti, G. M., And Razin, A. Current account sustainability: Selected east asian and latin american experiences. NBER Working Paper Series, 5791 (1996).

23 Milesi-Ferretti, G. M., And Razin, A. Sharp reductions in current account deficits: An empirical analysis. European Economic Review, 42 (1998), 897-908.

24 Nobile, A. Comment: Bayesian multinomial probit models with a normalization constraint. Journal of Econometrics 99 (2000), 335-345.

25 Train, K. E. Discrete Choice Methods with Simulation. Cambridge, 2003. 
Table 1: Number of reversals under different identification schemes

\begin{tabular}{lcccc}
\hline \hline & \multicolumn{4}{c}{ positive reversals } \\
\cline { 2 - 5 }$I$ & $I$ & $I I$ & $I I I$ & $I V$ \\
\cline { 2 - 5 }$I I$ & 127 & 86 & 82 & 56 \\
\cline { 2 - 5 }$I I I$ & - & 86 & 53 & 56 \\
\cline { 2 - 5 }$I V$ & - & - & 82 & 53 \\
\cline { 2 - 5 } all & \multicolumn{3}{c}{53} \\
\hline \# of observations & \multicolumn{3}{c}{1312} \\
\hline \hline
\end{tabular}

Notes: Reversals refers to a reduction of deficits; (all) gives the number of reversals identified under all schemes; (I) - refers to a $3 \%$ reduction of average current account over a period of three years when the maximum deficit after the reversal is below the minimum deficit before the reversal (II) - refers to a $3 \%$ reduction of average current account over a period of three years with no reversal allowed in the consecutive two years (III) - refers to a $5 \%$ reduction of average current account over a period of three years when the maximum deficit after the reversal is below the minimum deficit before the reversal (IV) - refers to a $5 \%$ reduction of average current account over a period of three years with no reversal allowed in the consecutive two years . 
Table 2: Pooled probit model - Bayesian estimates

\begin{tabular}{lcccc}
\hline \hline \multirow{4}{*}{ constant } & $I$ & $I I$ & $I I I$ & $I V$ \\
\cline { 2 - 5 } US real interest rate & -3.0364 & -2.0446 & -2.1408 & -1.5793 \\
& 0.1234 & 0.0575 & 0.0521 & $(1.0382)$ \\
OECD growth rate & $(0.0532)$ & $(0.0586)$ & $(0.0597)$ & 0.0351 \\
& 0.1346 & 0.1196 & 0.08899 & 0.0729 \\
openness & $(0.0715)$ & $(0.079)$ & $(0.0814)$ & $(0.095)$ \\
& -0.0014 & 0.0016 & -0.0025 & -0.0059 \\
mean CAD & $(0.0074)$ & $(0.0082)$ & $(0.008)$ & $(0.009)$ \\
& -0.0607 & -0.0494 & -0.0586 & -0.0459 \\
investment & $(0.0107)$ & $(0.0116)$ & $(0.0117)$ & $(0.0131)$ \\
mean growth & -0.0005 & -0.002 & 0.0038 & 0.0073 \\
reserves & $(0.0072)$ & $(0.008)$ & $(0.0079)$ & $(0.0087)$ \\
official transfers & 0.0121 & 0.0009 & 0.036 & 0.0165 \\
government & $(0.0197)$ & $(0.0216)$ & $(0.0233)$ & $(0.0259)$ \\
concessional debt & -0.0772 & -0.0493 & -0.0999 & -0.1121 \\
& $(0.0293)$ & $(0.0319)$ & $(0.0375)$ & $(0.0474)$ \\
terms of trade & -0.0092 & -0.0049 & 0.0085 & 0.0163 \\
& $(0.0106)$ & $(0.0118)$ & $(0.0118)$ & $(0.0128)$ \\
interest payments & 0.023 & 0.0093 & 0.0303 & 0.0161 \\
log initial GDP & $(0.0119)$ & $(0.0134)$ & $(0.0131)$ & $(0.0149)$ \\
& -0.0054 & -0.0092 & -0.0141 & -0.0189 \\
log(marg-lik) & $(0.0041)$ & $(0.0047)$ & $(0.0055)$ & $(0.006)$ \\
\hline \hline & -0.0032 & -0.0033 & -0.0076 & -0.0063 \\
& $(0.0016)$ & $(0.002)$ & $(0.0023)$ & $(0.0025)$ \\
& 0.0241 & -0.0062 & 0.0475 & 0.0136 \\
& $(0.0299)$ & $(0.0346)$ & $(0.0328)$ & $(0.037)$ \\
& 0.1089 & 0.0346 & 0.0521 & 0.0184 \\
& $(0.0865)$ & $(0.0946)$ & $(0.1003)$ & $(0.1135)$ \\
\hline
\end{tabular}

Notes: Standard errors are given in parenthesis; Estimates are based on 10,000 Gibbs draws with a Burn-In phase of 2,000 . 
Table 3: Pooled probit model with serial correlation - Bayesian estimates

\begin{tabular}{|c|c|c|c|c|}
\hline & $I$ & $I I$ & $I I I$ & $I V$ \\
\hline constant & $\begin{array}{c}-2.5930 \\
(1.2131)\end{array}$ & $\begin{array}{c}-2.0295 \\
(0.8235)\end{array}$ & $\begin{array}{c}-1.2858 \\
(1.4632)\end{array}$ & $\begin{array}{c}-1.5815 \\
(0.9657)\end{array}$ \\
\hline US real interest rate & $\begin{array}{l}0.1264 \\
(0.0571)\end{array}$ & $\begin{array}{l}0.0655 \\
(0.0558)\end{array}$ & $\begin{array}{l}0.0847 \\
(0.0651)\end{array}$ & $\begin{array}{l}0.0374 \\
(0.0655)\end{array}$ \\
\hline OECD growth rate & $\begin{array}{l}0.0907 \\
(0.0700)\end{array}$ & $\begin{array}{l}0.1149 \\
(0.0765)\end{array}$ & $\begin{array}{l}0.0539 \\
(0.0793)\end{array}$ & $\begin{array}{l}0.0791 \\
(0.0958)\end{array}$ \\
\hline openness & $\begin{array}{c}-0.0029 \\
(0.0059)\end{array}$ & $\begin{array}{l}0.0018 \\
(0.0081)\end{array}$ & $\begin{array}{c}-0.0034 \\
(0.0058)\end{array}$ & $\begin{array}{c}-0.0046 \\
(0.0089)\end{array}$ \\
\hline mean CAD & $\begin{array}{c}-0.0678 \\
(0.0148)\end{array}$ & $\begin{array}{c}-0.0477 \\
(0.0106)\end{array}$ & $\begin{array}{c}-0.0683 \\
(0.0159)\end{array}$ & $\begin{array}{c}-0.0439 \\
(0.0116)\end{array}$ \\
\hline investment & $\begin{array}{c}-0.0001 \\
(0.0058)\end{array}$ & $\begin{array}{c}-0.0025 \\
(0.0080)\end{array}$ & $\begin{array}{l}0.0057 \\
(0.0058)\end{array}$ & $\begin{array}{l}0.0060 \\
(0.0087)\end{array}$ \\
\hline mean growth rate & $\begin{array}{l}0.0077 \\
(0.0222)\end{array}$ & $\begin{array}{l}0.0016 \\
(0.0196)\end{array}$ & $\begin{array}{l}0.0258 \\
(0.0250)\end{array}$ & $\begin{array}{l}0.0137 \\
(0.0237)\end{array}$ \\
\hline reserves & $\begin{array}{c}-0.1351 \\
(0.0604)\end{array}$ & $\begin{array}{c}-0.0518 \\
(0.0289)\end{array}$ & $\begin{array}{c}-0.2196 \\
(0.0966)\end{array}$ & $\begin{array}{c}-0.1131 \\
(0.0405)\end{array}$ \\
\hline official transfers & $\begin{array}{c}-0.0033 \\
(0.0118)\end{array}$ & $\begin{array}{c}-0.0052 \\
(0.0107)\end{array}$ & $\begin{array}{l}0.0148 \\
(0.0129)\end{array}$ & $\begin{array}{l}0.0131 \\
(0.0121)\end{array}$ \\
\hline government & $\begin{array}{l}0.0064 \\
(0.0159)\end{array}$ & $\begin{array}{l}0.0098 \\
(0.0121)\end{array}$ & $\begin{array}{l}0.0059 \\
(0.0166)\end{array}$ & $\begin{array}{l}0.0169 \\
(0.0139)\end{array}$ \\
\hline concessional debt & $\begin{array}{c}-0.0071 \\
(0.0060)\end{array}$ & $\begin{array}{c}-0.0090 \\
(0.0042)\end{array}$ & $\begin{array}{c}-0.0193 \\
(0.0098)\end{array}$ & $\begin{array}{c}-0.0184 \\
(0.0056)\end{array}$ \\
\hline terms of trade & $\begin{array}{c}-0.0045 \\
(0.0026)\end{array}$ & $\begin{array}{c}-0.0036 \\
(0.0018)\end{array}$ & $\begin{array}{c}-0.0107 \\
(0.0039)\end{array}$ & $\begin{array}{c}-0.0056 \\
(0.0022)\end{array}$ \\
\hline interest payments & $\begin{array}{l}0.0274 \\
(0.0315)\end{array}$ & $\begin{array}{c}-0.0085 \\
(0.0321)\end{array}$ & $\begin{array}{l}0.0627 \\
(0.0334)\end{array}$ & $\begin{array}{l}0.0084 \\
(0.0354)\end{array}$ \\
\hline initial log GDP & $\begin{array}{l}0.1636 \\
(0.1481) \\
\end{array}$ & $\begin{array}{l}0.0361 \\
(0.0847)\end{array}$ & $\begin{array}{l}0.0714 \\
(0.1761) \\
\end{array}$ & $\begin{array}{l}0.0106 \\
(0.1034) \\
\end{array}$ \\
\hline$\rho$ & $\begin{array}{l}0.6394 \\
(0.1156) \\
\end{array}$ & $\begin{array}{c}-0.2702 \\
(0.1373)\end{array}$ & $\begin{array}{l}0.7518 \\
(0.1206) \\
\end{array}$ & $\begin{array}{c}-0.2564 \\
(0.1926)\end{array}$ \\
\hline $\log ($ marg-lik $)$ & -342.3638 & -291.6540 & -255.4477 & -209.1025 \\
\hline
\end{tabular}

Notes: Standard errors are given in parenthesis; Estimates are based on 10,000 Gibbs draws with a Burn-In phase of 2,000 . 
Table 4: Probit model with partial heterogeneity - Bayesian estimates

\begin{tabular}{|c|c|c|c|c|}
\hline & $I$ & $I I$ & $I I I$ & $I V$ \\
\hline constant & $\begin{array}{c}-3.3696 \\
(1.5184)\end{array}$ & $\begin{array}{c}-2.6568 \\
(1.5304)\end{array}$ & $\begin{array}{c}-3.0164 \\
(2.0218)\end{array}$ & $\begin{array}{c}-2.4461 \\
(1.7673)\end{array}$ \\
\hline US real interest rate & $\begin{array}{l}0.1469 \\
(0.0689)\end{array}$ & $\begin{array}{c}0.1064 \\
(0.077)\end{array}$ & $\begin{array}{l}0.0673 \\
(0.0834)\end{array}$ & $\begin{array}{l}0.0696 \\
(0.0895)\end{array}$ \\
\hline OECD growth rate & $\begin{array}{l}0.1549 \\
(0.0902)\end{array}$ & $\begin{array}{l}0.1353 \\
(0.0978)\end{array}$ & $\begin{array}{l}0.0428 \\
(0.1075)\end{array}$ & $\begin{array}{l}0.0393 \\
(0.1206)\end{array}$ \\
\hline $\log$ initial GDP & $\begin{array}{l}0.1909 \\
(0.1816)\end{array}$ & $\begin{array}{l}0.0936 \\
(0.1752)\end{array}$ & $\begin{array}{c}0.17 \\
(0.2375)\end{array}$ & $\begin{array}{l}0.0839 \\
(0.2096)\end{array}$ \\
\hline government & $\begin{array}{l}0.0238 \\
(0.0214)\end{array}$ & $\begin{array}{l}0.0225 \\
(0.0217)\end{array}$ & $\begin{array}{l}0.0295 \\
(0.0247)\end{array}$ & $\begin{array}{l}0.0362 \\
(0.0269)\end{array}$ \\
\hline concessional debt & $\begin{array}{c}-0.0035 \\
(0.0074)\end{array}$ & $\begin{array}{c}-0.0073 \\
(0.0073)\end{array}$ & $\begin{array}{c}-0.0056 \\
(0.0103)\end{array}$ & $\begin{array}{c}-0.0166 \\
(0.0103)\end{array}$ \\
\hline openness & $\begin{array}{c}-0.0142 \\
(0.0092)\end{array}$ & $\begin{array}{c}-0.0089 \\
(0.0097)\end{array}$ & $\begin{array}{c}-0.0183 \\
(0.0104)\end{array}$ & $\begin{array}{c}-0.0207 \\
(0.0108)\end{array}$ \\
\hline investment & $\begin{array}{c}0.009 \\
(0.0089)\end{array}$ & $\begin{array}{l}0.0064 \\
(0.0094)\end{array}$ & $\begin{array}{l}0.0167 \\
(0.0101)\end{array}$ & $\begin{array}{l}0.0195 \\
(0.0105)\end{array}$ \\
\hline interest payments & $\begin{array}{l}0.0663 \\
(0.0476)\end{array}$ & $\begin{array}{l}0.0121 \\
(0.0514)\end{array}$ & $\begin{array}{l}0.1649 \\
(0.0606)\end{array}$ & $\begin{array}{l}0.0712 \\
(0.0615)\end{array}$ \\
\hline mean growth & $\begin{array}{l}0.0407 \\
(0.0305)\end{array}$ & $\begin{array}{l}0.0293 \\
(0.0305)\end{array}$ & $\begin{array}{c}0.0839 \\
(0.038)\end{array}$ & $\begin{array}{l}0.0647 \\
(0.0392)\end{array}$ \\
\hline terms of trade & $\begin{array}{c}-0.0112 \\
(0.0036) \\
\end{array}$ & $\begin{array}{c}-0.0079 \\
(0.0034) \\
\end{array}$ & $\begin{array}{c}-0.0153 \\
(0.0051) \\
\end{array}$ & $\begin{array}{c}-0.0098 \\
(0.0045) \\
\end{array}$ \\
\hline mean CAD & $\begin{array}{c}-0.2032 \\
(0.0364)\end{array}$ & $\begin{array}{c}-0.1457 \\
(0.033)\end{array}$ & $\begin{array}{c}-0.1966 \\
(0.042)\end{array}$ & $\begin{array}{c}-0.1395 \\
(0.0368)\end{array}$ \\
\hline$\sigma_{\text {mean CAD }}$ & $\begin{array}{l}0.0182 \\
(0.0073)\end{array}$ & $\begin{array}{c}0.012 \\
(0.0047)\end{array}$ & $\begin{array}{l}0.0206 \\
(0.0085)\end{array}$ & $\begin{array}{l}0.0138 \\
(0.0058)\end{array}$ \\
\hline reserves & $\begin{array}{c}-0.2344 \\
(0.0766)\end{array}$ & $\begin{array}{c}-0.2027 \\
(0.0736)\end{array}$ & $\begin{array}{c}-0.3208 \\
(0.1083)\end{array}$ & $\begin{array}{c}-0.2879 \\
(0.0731)\end{array}$ \\
\hline$\sigma_{\text {reserves }}$ & $\begin{array}{l}0.0361 \\
(0.0216)\end{array}$ & $\begin{array}{l}0.0302 \\
(0.0223)\end{array}$ & $\begin{array}{l}0.0479 \\
(0.0307)\end{array}$ & $\begin{array}{l}0.0278 \\
(0.0172)\end{array}$ \\
\hline official transfers & $\begin{array}{l}-0.094 \\
(0.0425)\end{array}$ & $\begin{array}{c}-0.1214 \\
(0.0436)\end{array}$ & $\begin{array}{c}-0.0912 \\
(0.0494)\end{array}$ & $\begin{array}{c}-0.1132 \\
(0.0517)\end{array}$ \\
\hline$\sigma_{\text {official transfers }}$ & $\begin{array}{c}0.018 \\
(0.0083)\end{array}$ & $\begin{array}{l}0.0171 \\
(0.0073) \\
\end{array}$ & $\begin{array}{l}0.0214 \\
(0.0108) \\
\end{array}$ & $\begin{array}{l}0.0212 \\
(0.0101)\end{array}$ \\
\hline $\log ($ marg-lik $)$ & -313.2373 & -276.4419 & -234.6651 & -207.1352 \\
\hline
\end{tabular}

Notes: Standard errors are given in parenthesis; Estimates are based on 10,000 Gibbs draws with a Burn-In phase of 2,000 . 
Table 5: Probit model with partial heterogeneity and serial correlation- Bayesian estimates

\begin{tabular}{lcccc}
\hline \hline \multirow{2}{*}{ constant } & $I$ & $I I$ & $I I I$ & $I V$ \\
\cline { 2 - 5 } & -1.2346 & -0.9752 & -2.1076 & -0.6458 \\
official transfers & $(0.2074)$ & $(0.2403)$ & $(0.4368)$ & $(0.305)$ \\
& -0.0103 & -0.0046 & -0.0182 & 0.0134 \\
concessional debt & $-0.0155)$ & $(0.01)$ & $(0.0182)$ & $(0.0136)$ \\
& $(0.0045)$ & -0.0102 & 0.0076 & -0.0197 \\
terms of trade & -0.0009 & -0.0028 & 0.0015 & -0.0062 \\
& $(0.0009)$ & $(0.0018)$ & $(0.0026)$ & $(0.0025)$ \\
reserves & 0.0003 & -0.058 & 0.0063 & -0.1273 \\
& $(0.0007)$ & $(0.0273)$ & $(0.0033)$ & $(0.0465)$ \\
\hline \multirow{2}{*}{$\rho$} & 0.4945 & -0.2433 & 0.7450 & -0.2742 \\
& $(0.0815)$ & $(0.1255)$ & $(0.1235)$ & $(0.1889)$ \\
\hline \multirow{2}{*}{ mean CAD } & -0.0207 & -0.0489 & -0.1760 & -0.0789 \\
& $(0.0253)$ & $(0.013)$ & $(0.1260)$ & $(0.0206)$ \\
$\sigma_{\text {mean CAD }}^{2}$ & 0.0132 & 0.0002 & 0.2282 & 0.0014 \\
\hline log (marg-lik) & $(0.0088)$ & $(0.0004)$ & $(0.3324)$ & $(0.0012)$ \\
\hline \hline
\end{tabular}

Notes: Standard errors are given in parenthesis; Estimates are based on 10,000 Gibbs draws with a Burn-In phase of 2,000 . 
Table 6: Pooled treatment model - Bayesian estimates

\begin{tabular}{|c|c|c|c|c|}
\hline & $I$ & $I I$ & $I I I$ & $I V$ \\
\hline$\sigma$ & $\begin{array}{l}4.9960 \\
(0.1393)\end{array}$ & $\begin{array}{l}4.9527 \\
(0.1301)\end{array}$ & $\begin{array}{l}4.7916 \\
(0.1184)\end{array}$ & $\begin{array}{l}4.7849 \\
(0.1162)\end{array}$ \\
\hline$\rho$ & $\begin{array}{l}0.6590 \\
(0.0724) \\
\end{array}$ & $\begin{array}{l}0.6851 \\
(0.0893) \\
\end{array}$ & $\begin{array}{l}0.4079 \\
(0.1123) \\
\end{array}$ & $\begin{array}{l}0.4162 \\
(0.1404) \\
\end{array}$ \\
\hline constant & $\begin{array}{c}-2.6534 \\
(0.7592)\end{array}$ & $\begin{array}{c}-2.2508 \\
(0.8648)\end{array}$ & $\begin{array}{c}-2.1011 \\
(0.8903)\end{array}$ & $\begin{array}{c}-1.582 \\
(1.0588)\end{array}$ \\
\hline US real interest rate & $\begin{array}{l}0.1103 \\
(0.0449)\end{array}$ & $\begin{array}{c}0.0712 \\
(0.051)\end{array}$ & $\begin{array}{c}0.0501 \\
(0.056)\end{array}$ & $\begin{array}{c}0.032 \\
(0.0655)\end{array}$ \\
\hline OECD growth rate & $\begin{array}{l}0.1276 \\
(0.0619)\end{array}$ & $\begin{array}{l}0.1223 \\
(0.0724)\end{array}$ & $\begin{array}{l}0.0846 \\
(0.0803)\end{array}$ & $\begin{array}{l}0.0858 \\
(0.0873)\end{array}$ \\
\hline openness & $\begin{array}{c}-0.0016 \\
(0.0021)\end{array}$ & $\begin{array}{c}-0.0018 \\
(0.0023)\end{array}$ & $\begin{array}{c}0 \\
(0.0024)\end{array}$ & $\begin{array}{c}-0.0004 \\
(0.0027)\end{array}$ \\
\hline mean CAD & $\begin{array}{c}-0.0677 \\
(0.0113)\end{array}$ & $\begin{array}{c}-0.0591 \\
(0.0127)\end{array}$ & $\begin{array}{c}-0.0604 \\
(0.013)\end{array}$ & $\begin{array}{c}-0.0529 \\
(0.015)\end{array}$ \\
\hline investment & $\begin{array}{l}0.0023 \\
(0.0098)\end{array}$ & $\begin{array}{l}0.0067 \\
(0.0115)\end{array}$ & $\begin{array}{l}0.0139 \\
(0.0117)\end{array}$ & $\begin{array}{c}0.012 \\
(0.0136)\end{array}$ \\
\hline mean growth & $\begin{array}{l}0.0321 \\
(0.0187)\end{array}$ & $\begin{array}{l}0.0243 \\
(0.0211)\end{array}$ & $\begin{array}{l}0.0427 \\
(0.0238)\end{array}$ & $\begin{array}{l}0.0273 \\
(0.0273)\end{array}$ \\
\hline reserves & $\begin{array}{c}-0.0884 \\
(0.0263)\end{array}$ & $\begin{array}{c}-0.074 \\
(0.0289)\end{array}$ & $\begin{array}{c}-0.1246 \\
(0.0383)\end{array}$ & $\begin{array}{c}-0.1365 \\
(0.0479)\end{array}$ \\
\hline official transfers & $\begin{array}{c}-0.0356 \\
(0.0115)\end{array}$ & $\begin{array}{c}-0.0357 \\
(0.0131)\end{array}$ & $\begin{array}{c}-0.0116 \\
(0.0135)\end{array}$ & $\begin{array}{c}-0.0089 \\
(0.0156)\end{array}$ \\
\hline government & $\begin{array}{l}0.0128 \\
(0.0112)\end{array}$ & $\begin{array}{l}0.0005 \\
(0.0127)\end{array}$ & $\begin{array}{c}0.0292 \\
(0.013)\end{array}$ & $\begin{array}{l}0.0159 \\
(0.0147)\end{array}$ \\
\hline concessional debt & $\begin{array}{c}-0.0054 \\
(0.0037)\end{array}$ & $\begin{array}{c}-0.0073 \\
(0.0041)\end{array}$ & $\begin{array}{c}-0.0143 \\
(0.0054)\end{array}$ & $\begin{array}{c}-0.0187 \\
(0.0064)\end{array}$ \\
\hline terms of trade & $\begin{array}{c}-0.0022 \\
(0.0015)\end{array}$ & $\begin{array}{c}-0.0023 \\
(0.0018)\end{array}$ & $\begin{array}{c}-0.0067 \\
(0.0023)\end{array}$ & $\begin{array}{c}-0.0055 \\
(0.0025)\end{array}$ \\
\hline interest payments & $\begin{array}{l}0.0104 \\
(0.0273)\end{array}$ & $\begin{array}{l}-0.009 \\
(0.0297)\end{array}$ & $\begin{array}{l}0.0454 \\
(0.0333)\end{array}$ & $\begin{array}{l}0.0126 \\
(0.0353)\end{array}$ \\
\hline $\log$ initial GDP & $\begin{array}{l}0.0822 \\
(0.0779)\end{array}$ & $\begin{array}{c}0.057 \\
(0.0849) \\
\end{array}$ & $\begin{array}{c}0.03 \\
(0.0938) \\
\end{array}$ & $\begin{array}{l}0.0025 \\
(0.1082) \\
\end{array}$ \\
\hline constant & $\begin{array}{l}1.7255 \\
(1.0732)\end{array}$ & $\begin{array}{l}1.6683 \\
(1.0695)\end{array}$ & $\begin{array}{l}1.7096 \\
(1.0528)\end{array}$ & $\begin{array}{l}1.7853 \\
(1.0459)\end{array}$ \\
\hline lagged growth & $\begin{array}{l}0.1611 \\
(0.0324)\end{array}$ & $\begin{array}{c}0.16 \\
(0.032)\end{array}$ & $\begin{array}{l}0.1656 \\
(0.0315)\end{array}$ & $\begin{array}{l}0.1653 \\
(0.0319)\end{array}$ \\
\hline reversal & $\begin{array}{c}-6.9888 \\
(1.1753)\end{array}$ & $\begin{array}{l}-7.0228 \\
(1.4288)\end{array}$ & $\begin{array}{c}-5.7425 \\
(1.6464)\end{array}$ & $\begin{array}{c}-4.6573 \\
(1.9739)\end{array}$ \\
\hline reversal $\times$ openness & $\begin{array}{l}0.0101 \\
(0.0121)\end{array}$ & $\begin{array}{c}-0.0038 \\
(0.0145)\end{array}$ & $\begin{array}{l}0.0181 \\
(0.0145)\end{array}$ & $\begin{array}{c}-0.0031 \\
(0.0171)\end{array}$ \\
\hline $\log$ initial GDP & $\begin{array}{c}-0.0415 \\
(0.1502)\end{array}$ & $\begin{array}{c}-0.0645 \\
(0.1475)\end{array}$ & $\begin{array}{c}-0.0951 \\
(0.1465)\end{array}$ & $\begin{array}{c}-0.1049 \\
(0.1451)\end{array}$ \\
\hline openness & $\begin{array}{c}0.0089 \\
(0.005)\end{array}$ & $\begin{array}{l}0.0086 \\
(0.0048)\end{array}$ & $\begin{array}{l}0.0095 \\
(0.0047)\end{array}$ & $\begin{array}{l}0.0095 \\
(0.0047)\end{array}$ \\
\hline investment & $\begin{array}{l}0.0694 \\
(0.0236) \\
\end{array}$ & $\begin{array}{l}0.0713 \\
(0.0232) \\
\end{array}$ & $\begin{array}{l}0.0676 \\
(0.0227) \\
\end{array}$ & $\begin{array}{l}0.0632 \\
(0.0225) \\
\end{array}$ \\
\hline $\log$ (marg.-lik.) & -3280.0 & -3207.6 & -3199.2 & -3146.8 \\
\hline
\end{tabular}

Notes: Standard errors are given in parenthesis; Estimates are based on 10,000 Gibbs draws with a Burn-In phase of 2,000 . 
Table 7: Pooled treatment model with serial correlation- Bayesian estimates

\begin{tabular}{|c|c|c|c|c|}
\hline & $I$ & $I I$ & $I I I$ & $I V$ \\
\hline$\sigma$ & $\begin{array}{l}4.7175 \\
(0.1064)\end{array}$ & $\begin{array}{l}4.9252 \\
(0.1361)\end{array}$ & $\begin{array}{l}4.7248 \\
(0.1078)\end{array}$ & $\begin{array}{l}4.7808 \\
(0.1153)\end{array}$ \\
\hline$\rho$ & $\begin{array}{l}0.0615 \\
(0.0415)\end{array}$ & $\begin{array}{l}0.6294 \\
(0.1068)\end{array}$ & $\begin{array}{l}0.0238 \\
(0.0847)\end{array}$ & $\begin{array}{l}0.4177 \\
(0.1144)\end{array}$ \\
\hline$\psi$ & $\begin{array}{c}0.69 \\
(0.0912) \\
\end{array}$ & $\begin{array}{c}-0.2095 \\
(0.0843) \\
\end{array}$ & $\begin{array}{l}0.8017 \\
(0.0883) \\
\end{array}$ & $\begin{array}{c}-0.2873 \\
(0.1259) \\
\end{array}$ \\
\hline constant & $\begin{array}{c}-3.2006 \\
(1.9266)\end{array}$ & $\begin{array}{c}-1.7136 \\
(0.7045)\end{array}$ & $\begin{array}{c}-0.3652 \\
(1.2261)\end{array}$ & $\begin{array}{c}-1.0685 \\
(0.7614)\end{array}$ \\
\hline US real interest & $\begin{array}{l}0.1808 \\
(0.0825)\end{array}$ & $\begin{array}{l}0.0662 \\
(0.0495)\end{array}$ & $\begin{array}{l}0.1001 \\
(0.1135)\end{array}$ & $\begin{array}{l}0.0268 \\
(0.0599)\end{array}$ \\
\hline OECD growth & $\begin{array}{l}0.1302 \\
(0.0953)\end{array}$ & $\begin{array}{l}0.1132 \\
(0.0714)\end{array}$ & $\begin{array}{l}0.0765 \\
(0.1298)\end{array}$ & $\begin{array}{l}0.0715 \\
(0.0879)\end{array}$ \\
\hline openness & $\begin{array}{c}-0.0073 \\
(0.0063)\end{array}$ & $\begin{array}{c}-0.0015 \\
(0.0022)\end{array}$ & $\begin{array}{c}-0.0032 \\
(0.009)\end{array}$ & $\begin{array}{c}-0.0002 \\
(0.0025)\end{array}$ \\
\hline mean CAD & $\begin{array}{c}-0.1129 \\
(0.0352)\end{array}$ & $\begin{array}{c}-0.0634 \\
(0.0114)\end{array}$ & $\begin{array}{c}-0.1341 \\
(0.0482)\end{array}$ & $\begin{array}{l}-0.059 \\
(0.0134)\end{array}$ \\
\hline investment & $\begin{array}{l}0.0154 \\
(0.0296)\end{array}$ & $\begin{array}{l}0.0014 \\
(0.0103)\end{array}$ & $\begin{array}{l}0.0272 \\
(0.0455)\end{array}$ & $\begin{array}{l}0.0067 \\
(0.0124)\end{array}$ \\
\hline mean growth & $\begin{array}{l}0.0171 \\
(0.0359)\end{array}$ & $\begin{array}{l}0.0337 \\
(0.0216)\end{array}$ & $\begin{array}{l}0.0441 \\
(0.0553)\end{array}$ & $\begin{array}{l}0.0426 \\
(0.0261)\end{array}$ \\
\hline reserves & $\begin{array}{l}-0.199 \\
(0.0957)\end{array}$ & $\begin{array}{c}-0.0771 \\
(0.029)\end{array}$ & $\begin{array}{c}-0.4643 \\
(0.2608)\end{array}$ & $\begin{array}{c}-0.1344 \\
(0.0419)\end{array}$ \\
\hline official transfers & $\begin{array}{c}-0.0029 \\
(0.0183)\end{array}$ & $\begin{array}{c}-0.0416 \\
(0.0132)\end{array}$ & $\begin{array}{l}0.0367 \\
(0.0295)\end{array}$ & $\begin{array}{c}-0.0161 \\
(0.0155)\end{array}$ \\
\hline government & $\begin{array}{l}0.0083 \\
(0.0251)\end{array}$ & $\begin{array}{l}0.0013 \\
(0.0126)\end{array}$ & $\begin{array}{l}0.0014 \\
(0.0327)\end{array}$ & $\begin{array}{l}0.0183 \\
(0.0141)\end{array}$ \\
\hline concessional debt & $\begin{array}{c}-0.0122 \\
(0.0107)\end{array}$ & $\begin{array}{l}-0.009 \\
(0.0038)\end{array}$ & $\begin{array}{c}-0.0428 \\
(0.0251)\end{array}$ & $\begin{array}{c}-0.0216 \\
(0.0053)\end{array}$ \\
\hline terms of trade & $\begin{array}{c}-0.0088 \\
(0.0054)\end{array}$ & $\begin{array}{c}-0.0024 \\
(0.0017)\end{array}$ & $\begin{array}{c}-0.0202 \\
(0.0092)\end{array}$ & $\begin{array}{l}-0.006 \\
(0.0024)\end{array}$ \\
\hline interest payments & $\begin{array}{l}0.0534 \\
(0.0529)\end{array}$ & $\begin{array}{c}-0.0104 \\
(0.0284)\end{array}$ & $\begin{array}{c}0.112 \\
(0.0772)\end{array}$ & $\begin{array}{l}0.0077 \\
(0.0352)\end{array}$ \\
\hline $\log$ initial GDP & $\begin{array}{r}0.1736 \\
(0.2237) \\
\end{array}$ & $\begin{array}{c}-0.0028 \\
(0.0753) \\
\end{array}$ & $\begin{array}{c}-0.0115 \\
(0.2469) \\
\end{array}$ & $\begin{array}{c}-0.0512 \\
(0.0895) \\
\end{array}$ \\
\hline constant & $\begin{array}{c}2.1346 \\
(1.02)\end{array}$ & $\begin{array}{l}1.8294 \\
(1.0632)\end{array}$ & $\begin{array}{l}2.0667 \\
(1.0168)\end{array}$ & $\begin{array}{l}1.8159 \\
(1.0353)\end{array}$ \\
\hline lagged growth & $\begin{array}{l}0.1687 \\
(0.0318)\end{array}$ & $\begin{array}{l}0.1506 \\
(0.0323)\end{array}$ & $\begin{array}{l}0.1682 \\
(0.0315)\end{array}$ & $\begin{array}{c}0.1604 \\
(0.031)\end{array}$ \\
\hline reversal & $\begin{array}{c}-1.8179 \\
(1.0944)\end{array}$ & $\begin{array}{c}-6.4924 \\
(1.5623)\end{array}$ & $\begin{array}{c}-2.4207 \\
(1.4204)\end{array}$ & $\begin{array}{l}-4.533 \\
(1.7857)\end{array}$ \\
\hline reversal $\times$ openness & $\begin{array}{l}0.0082 \\
(0.0134)\end{array}$ & $\begin{array}{c}-0.0033 \\
(0.0145)\end{array}$ & $\begin{array}{l}0.0147 \\
(0.0153)\end{array}$ & $\begin{array}{c}-0.0038 \\
(0.0165)\end{array}$ \\
\hline $\log$ initial GDP & $\begin{array}{c}-0.1344 \\
(0.1421)\end{array}$ & $\begin{array}{c}-0.0844 \\
(0.1469)\end{array}$ & $\begin{array}{c}-0.1361 \\
(0.1411)\end{array}$ & $\begin{array}{c}-0.1117 \\
(0.1439)\end{array}$ \\
\hline openness & $\begin{array}{l}0.0078 \\
(0.0047)\end{array}$ & $\begin{array}{l}0.0088 \\
(0.0048)\end{array}$ & $\begin{array}{l}0.0077 \\
(0.0046)\end{array}$ & $\begin{array}{l}0.0097 \\
(0.0047)\end{array}$ \\
\hline investment & $\begin{array}{l}0.0571 \\
(0.0222) \\
\end{array}$ & $\begin{array}{l}0.0692 \\
(0.0236)\end{array}$ & $\begin{array}{l}0.0588 \\
(0.0221)\end{array}$ & $\begin{array}{l}0.0638 \\
(0.0224) \\
\end{array}$ \\
\hline $\log$ (marg.-lik.) & -3031.7 & -2788.1 & -2975.3 & -2875.9 \\
\hline
\end{tabular}

Notes: Standard errors are given in parenthesis; Estimates are based on 10,000 Gibbs draws with a Burn-In phase of 2,000 . 
Table 8: Pooled treatment model with serial correlation and heterogeneity - Bayesian estimates

\begin{tabular}{|c|c|c|c|c|}
\hline & $I$ & $I I$ & $I I I$ & $I V$ \\
\hline constant & $\begin{array}{c}-2.1111 \\
(1.2305)\end{array}$ & $\begin{array}{c}-1.1648 \\
(0.3194)\end{array}$ & $\begin{array}{c}-0.4880 \\
(0.9079)\end{array}$ & $\begin{array}{c}-0.8925 \\
(0.3652)\end{array}$ \\
\hline investment & $\begin{array}{l}0.0772 \\
(0.0339)\end{array}$ & $\begin{array}{l}0.0119 \\
(0.0093)\end{array}$ & $\begin{array}{l}0.0096 \\
(0.0254)\end{array}$ & $\begin{array}{l}0.0162 \\
(0.0104)\end{array}$ \\
\hline reserves & $\begin{array}{c}-0.4714 \\
(0.1154)\end{array}$ & $\begin{array}{c}-0.0624 \\
(0.029)\end{array}$ & $\begin{array}{c}-0.1684 \\
(0.0837)\end{array}$ & $\begin{array}{c}-0.1362 \\
(0.0402)\end{array}$ \\
\hline concessional debt & $\begin{array}{c}-0.0239 \\
(0.0107)\end{array}$ & $\begin{array}{c}-0.013 \\
(0.003)\end{array}$ & $\begin{array}{c}-0.0189 \\
(0.0096)\end{array}$ & $\begin{array}{l}-0.021 \\
(0.0042)\end{array}$ \\
\hline terms of trade & $\begin{array}{c}-0.0167 \\
(0.0062) \\
\end{array}$ & $\begin{array}{c}-0.0029 \\
(0.0018) \\
\end{array}$ & $\begin{array}{c}-0.0137 \\
(0.0058) \\
\end{array}$ & $\begin{array}{c}-0.0059 \\
(0.0023) \\
\end{array}$ \\
\hline constant & $\begin{array}{c}2.2357 \\
(1.086)\end{array}$ & $\begin{array}{l}1.9848 \\
(1.1371)\end{array}$ & $\begin{array}{l}2.0550 \\
(1.0972)\end{array}$ & $\begin{array}{l}1.9557 \\
(1.1318)\end{array}$ \\
\hline reversal & $\begin{array}{c}-2.8228 \\
(1.3205)\end{array}$ & $\begin{array}{c}-6.1544 \\
(1.8027)\end{array}$ & $\begin{array}{c}-1.6276 \\
(1.2277)\end{array}$ & $\begin{array}{c}-4.7567 \\
(1.9904)\end{array}$ \\
\hline reversal $\times$ openness & $\begin{array}{l}0.0176 \\
(0.0151)\end{array}$ & $\begin{array}{l}0.0041 \\
(0.0153)\end{array}$ & $\begin{array}{l}0.0058 \\
(0.0135)\end{array}$ & $\begin{array}{c}0.004 \\
(0.0178)\end{array}$ \\
\hline openness & $\begin{array}{c}0.003 \\
(0.0051)\end{array}$ & $\begin{array}{c}0.0042 \\
(0.005)\end{array}$ & $\begin{array}{l}0.0047 \\
(0.0049)\end{array}$ & $\begin{array}{c}0.0044 \\
(0.005)\end{array}$ \\
\hline investment & $\begin{array}{l}0.0381 \\
(0.0251)\end{array}$ & $\begin{array}{c}0.045 \\
(0.0249)\end{array}$ & $\begin{array}{l}0.0335 \\
(0.0252)\end{array}$ & $\begin{array}{l}0.0416 \\
(0.0241)\end{array}$ \\
\hline $\log$ initial GDP & $\begin{array}{c}-0.0893 \\
(0.1486) \\
\end{array}$ & $\begin{array}{l}-0.037 \\
(0.1583) \\
\end{array}$ & $\begin{array}{c}-0.0707 \\
(0.1544) \\
\end{array}$ & $\begin{array}{c}-0.0575 \\
(0.1592) \\
\end{array}$ \\
\hline$\psi$ & $\begin{array}{l}0.7647 \\
(0.0522)\end{array}$ & $\begin{array}{c}-0.2365 \\
(0.1083)\end{array}$ & $\begin{array}{l}0.6434 \\
(0.0787)\end{array}$ & $\begin{array}{c}-0.2184 \\
(0.1537)\end{array}$ \\
\hline$\rho$ & $\begin{array}{l}0.0752 \\
(0.2326)\end{array}$ & $\begin{array}{l}2.5086 \\
(0.6693)\end{array}$ & $\begin{array}{l}0.1557 \\
(0.4331)\end{array}$ & $\begin{array}{l}1.6013 \\
(0.5775)\end{array}$ \\
\hline$\sigma^{2}$ & $\begin{array}{c}20.9242 \\
(0.9072)\end{array}$ & $\begin{array}{c}22.1117 \\
(1.2619)\end{array}$ & $\begin{array}{c}20.7642 \\
(0.9853)\end{array}$ & $\begin{array}{c}21.1554 \\
(1.0446)\end{array}$ \\
\hline lagged growth & $\begin{array}{l}0.2289 \\
(0.0445)\end{array}$ & $\begin{array}{l}0.1992 \\
(0.0442)\end{array}$ & $\begin{array}{l}0.2598 \\
(0.0532)\end{array}$ & $\begin{array}{l}0.2135 \\
(0.0416)\end{array}$ \\
\hline$\sigma_{\text {lagged growth }}^{2}$ & $\begin{array}{l}0.0345 \\
(0.0127)\end{array}$ & $\begin{array}{c}0.039 \\
(0.0134)\end{array}$ & $\begin{array}{l}0.0413 \\
(0.0142)\end{array}$ & $\begin{array}{l}0.0375 \\
(0.0131)\end{array}$ \\
\hline mean CAD & $\begin{array}{c}-0.2589 \\
(0.0731)\end{array}$ & $\begin{array}{c}-0.0512 \\
(0.015)\end{array}$ & $\begin{array}{c}-0.2412 \\
(0.0517)\end{array}$ & $\begin{array}{c}-0.0608 \\
(0.0125)\end{array}$ \\
\hline$\sigma_{\text {mean } \mathrm{CAD}}^{2}$ & $\begin{array}{l}0.0946 \\
(0.0388) \\
\end{array}$ & $\begin{array}{l}0.0005 \\
(0.0007) \\
\end{array}$ & $\begin{array}{l}0.0375 \\
(0.0273) \\
\end{array}$ & $\begin{array}{l}0.0002 \\
(0.0006) \\
\end{array}$ \\
\hline $\log$ (marg.-lik.) & -3025.6 & -2689.4 & -3010.3 & -2884.3 \\
\hline
\end{tabular}

Notes: Standard errors are given in parenthesis; Estimates are based on 10,000 Gibbs draws with a Burn-In phase of 2,000 . 
Table 9: Pooled probit model - Maximum likelihood estimates

\begin{tabular}{lcccc}
\hline \hline & I & II & III & IV \\
\cline { 2 - 5 } constant & -3.1686 & -2.4011 & -2.4392 & -1.7994 \\
& $(0.8393)$ & $(0.9497)$ & $(1.0009)$ & $(1.1439)$ \\
US real interest rate & 0.1286 & 0.0660 & 0.0511 & 0.0245 \\
& $(0.0506)$ & $(0.0615)$ & $(0.0616)$ & $(0.0731)$ \\
OECD growth rate & 0.1342 & 0.1143 & 0.0868 & 0.0731 \\
& $(0.0693)$ & $(0.0827)$ & $(0.0841)$ & $(0.1009)$ \\
openness & -0.0016 & -0.0010 & 0.0003 & 0.0004 \\
& $(0.0022)$ & $(0.0026)$ & $(0.0024)$ & $(0.0028)$ \\
mean growth & 0.0129 & -0.0056 & 0.0283 & 0.0083 \\
& $(0.0205)$ & $(0.0250)$ & $(0.0265)$ & $(0.0313)$ \\
mean investment & -0.0007 & 0.0081 & 0.0124 & 0.0123 \\
& $(0.0103)$ & $(0.0124)$ & $(0.0126)$ & $(0.0156)$ \\
interest payments & 0.0239 & -0.0003 & 0.0513 & 0.0189 \\
mean CAD & $(0.0302)$ & $(0.0372)$ & $(0.0353)$ & $(0.0406)$ \\
reserves & -0.0600 & -0.0446 & -0.0514 & -0.0404 \\
government & $(0.0115)$ & $(0.0134)$ & $(0.0134)$ & $(0.0145)$ \\
concessional debt & -0.0749 & -0.0507 & -0.1045 & -0.1135 \\
& $(0.0301)$ & $(0.0378)$ & $(0.0446)$ & $(0.0526)$ \\
official transfers & 0.0225 & 0.0094 & 0.0296 & 0.0171 \\
& $(0.0116)$ & $(0.0149)$ & $(0.0139)$ & $(0.0156)$ \\
terms of trade & -0.0049 & -0.0077 & -0.0122 & -0.0171 \\
initial log GDP & $(0.0042)$ & $(0.0048)$ & $(0.0057)$ & $(0.0068)$ \\
& -0.0083 & -0.0037 & 0.0076 & 0.0133 \\
log-lik. & $(0.0105)$ & $(0.0117)$ & $(0.0127)$ & $(0.0137)$ \\
\hline \hline & -0.0031 & -0.0031 & -0.0072 & -0.0059 \\
& $(0.0017)$ & $(0.0021)$ & $(0.0025)$ & $(0.0027)$ \\
& 0.1214 & 0.0580 & 0.0698 & 0.0307 \\
& $(0.0884)$ & $(0.1006)$ & $(0.1073)$ & $(0.1251)$ \\
\hline
\end{tabular}

Notes: Asymptotic standard errors are given in parenthesis. 
Table 10: Pooled probit model with serial correlation - Maximum likelihood estimates

\begin{tabular}{|c|c|c|c|c|c|c|c|c|}
\hline & $I$ & $\mathrm{MC}$ & $I I$ & $\mathrm{MC}$ & $I I I$ & $\mathrm{MC}$ & $I V$ & $\mathrm{MC}$ \\
\hline constant & $\begin{array}{c}-2.8037 \\
(1.3356)\end{array}$ & $\begin{array}{l}0.0944 \\
(0.0835)\end{array}$ & $\begin{array}{l}-2.401 \\
(1.1579)\end{array}$ & $\begin{array}{l}0.0138 \\
(0.0785)\end{array}$ & $\begin{array}{c}-1.3178 \\
(1.4591)\end{array}$ & $\begin{array}{c}0.1514 \\
(0.144)\end{array}$ & $\begin{array}{c}-1.4021 \\
(1.2513)\end{array}$ & $\begin{array}{l}0.0195 \\
(0.0737)\end{array}$ \\
\hline US real interest rate & $\begin{array}{c}0.106 \\
(0.0892)\end{array}$ & $\begin{array}{l}0.0103 \\
(0.0021)\end{array}$ & $\begin{array}{l}0.0881 \\
(0.0954)\end{array}$ & $\begin{array}{c}0.0027 \\
(0.003)\end{array}$ & $\begin{array}{c}-0.0442 \\
(0.109)\end{array}$ & $\begin{array}{l}0.0172 \\
(0.0021)\end{array}$ & $\begin{array}{c}-0.0743 \\
(0.1097)\end{array}$ & $\begin{array}{l}0.0032 \\
(0.0025)\end{array}$ \\
\hline OECD growth rate & $\begin{array}{c}0.0551 \\
(0.101)\end{array}$ & $\begin{array}{l}0.0096 \\
(0.0023)\end{array}$ & $\begin{array}{c}0.078 \\
(0.1101)\end{array}$ & $\begin{array}{c}0.004 \\
(0.0033)\end{array}$ & $\begin{array}{l}0.1008 \\
(0.1213)\end{array}$ & $\begin{array}{l}0.0174 \\
(0.0017)\end{array}$ & $\begin{array}{l}0.1422 \\
(0.1262)\end{array}$ & $\begin{array}{l}0.0042 \\
(0.0027)\end{array}$ \\
\hline openness & $\begin{array}{c}-0.0046 \\
(0.0037)\end{array}$ & $\begin{array}{l}0.0002 \\
(0.0001)\end{array}$ & $\begin{array}{c}-0.0012 \\
(0.0033)\end{array}$ & $\begin{array}{c}0 \\
(0.0002)\end{array}$ & $\begin{array}{c}-0.0006 \\
(0.0041)\end{array}$ & $\begin{array}{l}0.0003 \\
(0.0001)\end{array}$ & $\begin{array}{l}0.0007 \\
(0.0035)\end{array}$ & $\begin{array}{c}0 \\
(0.0002)\end{array}$ \\
\hline mean CAD & $\begin{array}{c}-0.0885 \\
(0.0205)\end{array}$ & $\begin{array}{l}0.0036 \\
(0.0018)\end{array}$ & $\begin{array}{l}-0.044 \\
(0.0155)\end{array}$ & $\begin{array}{l}0.0001 \\
(0.0008)\end{array}$ & $\begin{array}{c}-0.1011 \\
(0.0247)\end{array}$ & $\begin{array}{l}0.0057 \\
(0.0023)\end{array}$ & $\begin{array}{l}-0.041 \\
(0.0169)\end{array}$ & $\begin{array}{c}0.0002 \\
(0.001)\end{array}$ \\
\hline investment & $\begin{array}{l}0.0112 \\
(0.0169)\end{array}$ & $\begin{array}{l}0.0009 \\
(0.0006)\end{array}$ & $\begin{array}{l}0.0077 \\
(0.0162)\end{array}$ & $\begin{array}{l}0.0001 \\
(0.0011)\end{array}$ & $\begin{array}{l}0.0264 \\
(0.0203)\end{array}$ & $\begin{array}{l}0.0016 \\
(0.0004)\end{array}$ & $\begin{array}{l}0.0126 \\
(0.0179)\end{array}$ & $\begin{array}{l}0.0002 \\
(0.0013)\end{array}$ \\
\hline reserves & $\begin{array}{c}-0.1414 \\
(0.0512)\end{array}$ & $\begin{array}{l}0.0071 \\
(0.0034)\end{array}$ & $\begin{array}{c}-0.0542 \\
(0.0401)\end{array}$ & $\begin{array}{l}0.0004 \\
(0.0029)\end{array}$ & $\begin{array}{c}-0.2578 \\
(0.0827)\end{array}$ & $\begin{array}{l}0.0172 \\
(0.0064)\end{array}$ & $\begin{array}{c}-0.1096 \\
(0.0572)\end{array}$ & $\begin{array}{l}0.0009 \\
(0.0052)\end{array}$ \\
\hline mean growth & $\begin{array}{l}0.0118 \\
(0.0279)\end{array}$ & $\begin{array}{c}0.001 \\
(0.0007)\end{array}$ & $\begin{array}{c}-0.0056 \\
(0.0301)\end{array}$ & $\begin{array}{l}0.0002 \\
(0.0014)\end{array}$ & $\begin{array}{l}0.0368 \\
(0.0354)\end{array}$ & $\begin{array}{l}0.0028 \\
(0.0005)\end{array}$ & $\begin{array}{l}0.0065 \\
(0.0336)\end{array}$ & $\begin{array}{l}0.0002 \\
(0.0006)\end{array}$ \\
\hline official transfers & $\begin{array}{c}-0.0036 \\
(0.0143)\end{array}$ & $\begin{array}{l}0.0008 \\
(0.0003)\end{array}$ & $\begin{array}{c}-0.0044 \\
(0.0145)\end{array}$ & $\begin{array}{l}0.0002 \\
(0.0004)\end{array}$ & $\begin{array}{l}0.02 \\
(0.016)\end{array}$ & $\begin{array}{l}0.0023 \\
(0.0004)\end{array}$ & $\begin{array}{l}0.0106 \\
(0.0159)\end{array}$ & $\begin{array}{l}0.0001 \\
(0.0002)\end{array}$ \\
\hline government & $\begin{array}{c}0.015 \\
(0.0186)\end{array}$ & $\begin{array}{l}0.0013 \\
(0.0005)\end{array}$ & $\begin{array}{l}0.0114 \\
(0.0178)\end{array}$ & $\begin{array}{c}0.0002 \\
(0.001)\end{array}$ & $\begin{array}{c}0.0153 \\
(0.02)\end{array}$ & $\begin{array}{l}0.0015 \\
(0.0003)\end{array}$ & $\begin{array}{c}0.019 \\
(0.0191)\end{array}$ & $\begin{array}{l}0.0002 \\
(0.0005)\end{array}$ \\
\hline concessional debt & $\begin{array}{c}-0.0089 \\
(0.0063)\end{array}$ & $\begin{array}{l}0.0005 \\
(0.0003)\end{array}$ & $\begin{array}{c}-0.0084 \\
(0.0057)\end{array}$ & $\begin{array}{l}0.0001 \\
(0.0002)\end{array}$ & $\begin{array}{c}-0.0264 \\
(0.0101)\end{array}$ & $\begin{array}{l}0.0019 \\
(0.0007)\end{array}$ & $\begin{array}{l}-0.018 \\
(0.0074)\end{array}$ & $\begin{array}{l}0.0001 \\
(0.0004)\end{array}$ \\
\hline terms of trade & $\begin{array}{c}-0.0061 \\
(0.0031)\end{array}$ & $\begin{array}{l}0.0004 \\
(0.0002)\end{array}$ & $\begin{array}{c}-0.0029 \\
(0.0024)\end{array}$ & $\begin{array}{c}0 \\
(0.0001)\end{array}$ & $\begin{array}{c}-0.0145 \\
(0.0045)\end{array}$ & $\begin{array}{c}0.001 \\
(0.0004)\end{array}$ & $\begin{array}{c}-0.0058 \\
(0.0033)\end{array}$ & $\begin{array}{c}0 \\
(0.0001)\end{array}$ \\
\hline interest payments & $\begin{array}{c}0.0506 \\
(0.042)\end{array}$ & $\begin{array}{c}0.0034 \\
(0.001)\end{array}$ & $\begin{array}{c}-0.0008 \\
(0.0439)\end{array}$ & $\begin{array}{l}0.0003 \\
(0.0032)\end{array}$ & $\begin{array}{l}0.0841 \\
(0.0455)\end{array}$ & $\begin{array}{l}0.0073 \\
(0.0013)\end{array}$ & $\begin{array}{l}0.0141 \\
(0.0427)\end{array}$ & $\begin{array}{l}0.0006 \\
(0.0008)\end{array}$ \\
\hline log initial GDP & $\begin{array}{l}0.1556 \\
(0.1438) \\
\end{array}$ & $\begin{array}{l}0.0067 \\
(0.0066)\end{array}$ & $\begin{array}{l}0.0493 \\
(0.1216) \\
\end{array}$ & $\begin{array}{l}0.0009 \\
(0.0093) \\
\end{array}$ & $\begin{array}{l}0.0645 \\
(0.1639) \\
\end{array}$ & $\begin{array}{l}0.0117 \\
(0.0127) \\
\end{array}$ & $\begin{array}{l}0.0153 \\
(0.1427)\end{array}$ & $\begin{array}{c}0.001 \\
(0.0077) \\
\end{array}$ \\
\hline$\rho$ & $\begin{array}{l}0.5946 \\
(0.0732)\end{array}$ & $\begin{array}{l}0.0183 \\
(0.0074)\end{array}$ & $\begin{array}{c}-0.2619 \\
(0.1176)\end{array}$ & $\begin{array}{l}0.0142 \\
(0.0072)\end{array}$ & $\begin{array}{l}0.7257 \\
(0.0807)\end{array}$ & $\begin{array}{l}0.0224 \\
(0.0118)\end{array}$ & $\begin{array}{c}-0.2514 \\
(0.1569)\end{array}$ & $\begin{array}{c}0.0159 \\
(0.008)\end{array}$ \\
\hline log-lik. & -253.9233 & 0.6112 & -200.4599 & 0.2045 & -169.0650 & 0.6294 & -139.4507 & 0.1447 \\
\hline
\end{tabular}

Notes: Asymptotic standard errors are given in paranthesis; Results are based on 200 replications; MC errors are based on 20 replications. 
Table 11: Partial Random Coefficients - Simulated Likelihood estimates

\begin{tabular}{|c|c|c|c|c|c|c|c|c|}
\hline & $I$ & $M C$ & $I I$ & $M C$ & $I I I$ & $M C$ & $I V$ & $M C$ \\
\hline constant & $\begin{array}{c}-3.2651 \\
(1.2366)\end{array}$ & $\begin{array}{l}0.0639 \\
(0.0721)\end{array}$ & $\begin{array}{c}-2.2276 \\
(1.2155)\end{array}$ & $\begin{array}{c}0.0256 \\
(0.079)\end{array}$ & $\begin{array}{c}-2.5968 \\
(1.4952)\end{array}$ & $\begin{array}{l}0.1154 \\
(0.1088)\end{array}$ & $\begin{array}{c}-1.671 \\
(1.1933)\end{array}$ & $\begin{array}{c}0.024 \\
(0.1202)\end{array}$ \\
\hline US real interest rate & $\begin{array}{l}0.1177 \\
(0.0702)\end{array}$ & $\begin{array}{l}0.0013 \\
(0.0037)\end{array}$ & $\begin{array}{l}0.0706 \\
(0.0761)\end{array}$ & $\begin{array}{l}0.0019 \\
(0.0025)\end{array}$ & $\begin{array}{l}0.0407 \\
(0.0824)\end{array}$ & $\begin{array}{l}0.0028 \\
(0.0037)\end{array}$ & $\begin{array}{l}0.0426 \\
(0.0854)\end{array}$ & $\begin{array}{l}0.0022 \\
(0.0066)\end{array}$ \\
\hline OECD growth rate & $\begin{array}{l}0.1348 \\
(0.0929)\end{array}$ & $\begin{array}{l}0.0022 \\
(0.0035)\end{array}$ & $\underset{(0.1)}{0.1136}$ & $\begin{array}{l}0.0013 \\
(0.0028)\end{array}$ & $\begin{array}{l}0.0555 \\
(0.1081)\end{array}$ & $\begin{array}{l}0.0024 \\
(0.0045)\end{array}$ & $\begin{array}{c}0.0567 \\
(0.12)\end{array}$ & $\begin{array}{l}0.0016 \\
(0.0118)\end{array}$ \\
\hline $\log$ initial GDP & $\begin{array}{l}0.1285 \\
(0.1355)\end{array}$ & $\begin{array}{l}0.0072 \\
(0.0094)\end{array}$ & $\begin{array}{c}0.022 \\
(0.1261)\end{array}$ & $\begin{array}{l}0.0027 \\
(0.0084)\end{array}$ & $\begin{array}{l}0.1025 \\
(0.1698)\end{array}$ & $\begin{array}{l}0.0124 \\
(0.0095)\end{array}$ & $\begin{array}{c}-0.0052 \\
(0.14)\end{array}$ & $\begin{array}{l}0.0032 \\
(0.0103)\end{array}$ \\
\hline government & $\begin{array}{l}0.0233 \\
(0.0192)\end{array}$ & $\begin{array}{l}0.0011 \\
(0.0012)\end{array}$ & $\begin{array}{l}0.0104 \\
(0.0197)\end{array}$ & $\begin{array}{l}0.0006 \\
(0.0014)\end{array}$ & $\begin{array}{l}0.0296 \\
(0.0224)\end{array}$ & $\begin{array}{l}0.0018 \\
(0.0013)\end{array}$ & $\begin{array}{c}0.0212 \\
(0.022)\end{array}$ & $\begin{array}{l}0.0008 \\
(0.0014)\end{array}$ \\
\hline concessional debt & $\begin{array}{c}-0.0035 \\
(0.0058)\end{array}$ & $\begin{array}{l}0.0003 \\
(0.0004)\end{array}$ & $\begin{array}{c}-0.0084 \\
(0.0063)\end{array}$ & $\begin{array}{l}0.0002 \\
(0.0007)\end{array}$ & $\begin{array}{c}-0.0089 \\
(0.0083)\end{array}$ & $\begin{array}{l}0.0005 \\
(0.0006)\end{array}$ & $\begin{array}{c}-0.0187 \\
(0.0081)\end{array}$ & $\begin{array}{l}0.0004 \\
(0.0005)\end{array}$ \\
\hline openness & $\begin{array}{c}-0.0095 \\
(0.0095)\end{array}$ & $\begin{array}{l}0.0003 \\
(0.0004)\end{array}$ & $\begin{array}{l}-0.004 \\
(0.0102)\end{array}$ & $\begin{array}{l}0.0002 \\
(0.0003)\end{array}$ & $\begin{array}{c}-0.0133 \\
(0.0101)\end{array}$ & $\begin{array}{l}0.0003 \\
(0.0003)\end{array}$ & $\begin{array}{c}-0.0141 \\
(0.0115)\end{array}$ & $\begin{array}{l}0.0003 \\
(0.0009)\end{array}$ \\
\hline investment & $\begin{array}{l}0.0066 \\
(0.0092)\end{array}$ & $\begin{array}{l}0.0002 \\
(0.0004)\end{array}$ & $\begin{array}{l}0.0028 \\
(0.0098)\end{array}$ & $\begin{array}{l}0.0001 \\
(0.0003)\end{array}$ & $\begin{array}{l}0.0129 \\
(0.0098)\end{array}$ & $\begin{array}{l}0.0002 \\
(0.0004)\end{array}$ & $\begin{array}{l}0.0138 \\
(0.0111)\end{array}$ & $\begin{array}{l}0.0002 \\
(0.0008)\end{array}$ \\
\hline interest payments & $\begin{array}{l}0.0525 \\
(0.0457)\end{array}$ & $\begin{array}{l}0.0022 \\
(0.0039)\end{array}$ & $\begin{array}{c}0.006 \\
(0.0472)\end{array}$ & $\begin{array}{l}0.0022 \\
(0.0041)\end{array}$ & $\begin{array}{l}0.1182 \\
(0.0571)\end{array}$ & $\begin{array}{l}0.0028 \\
(0.0033)\end{array}$ & $\begin{array}{l}0.0379 \\
(0.0532)\end{array}$ & $\begin{array}{l}0.0026 \\
(0.0051)\end{array}$ \\
\hline mean growth & $\begin{array}{l}0.0324 \\
(0.0298)\end{array}$ & $\begin{array}{c}0.001 \\
(0.0022)\end{array}$ & $\begin{array}{l}0.0186 \\
(0.0319)\end{array}$ & $\begin{array}{l}0.0005 \\
(0.0018)\end{array}$ & $\begin{array}{c}0.071 \\
(0.0368)\end{array}$ & $\begin{array}{l}0.0016 \\
(0.0018)\end{array}$ & $\begin{array}{l}0.0458 \\
(0.0379)\end{array}$ & $\begin{array}{l}0.0009 \\
(0.0039)\end{array}$ \\
\hline terms of trade & $\begin{array}{c}-0.0066 \\
(0.0032)\end{array}$ & $\begin{array}{l}0.0002 \\
(0.0003) \\
\end{array}$ & $\begin{array}{c}-0.0027 \\
(0.0028)\end{array}$ & $\begin{array}{l}0.0002 \\
(0.0002) \\
\end{array}$ & $\begin{array}{c}-0.0112 \\
(0.0042)\end{array}$ & $\begin{array}{l}0.0002 \\
(0.0003)\end{array}$ & $\begin{array}{c}-0.0056 \\
(0.0036)\end{array}$ & $\begin{array}{l}0.0002 \\
(0.0003) \\
\end{array}$ \\
\hline mean CAD & $\begin{array}{c}-0.1519 \\
(0.0289)\end{array}$ & $\begin{array}{l}0.0031 \\
(0.0021)\end{array}$ & $\begin{array}{l}-0.081 \\
(0.0246)\end{array}$ & $\begin{array}{l}0.0035 \\
(0.0025)\end{array}$ & $\begin{array}{c}-0.1462 \\
(0.0313)\end{array}$ & $\begin{array}{l}0.0046 \\
(0.0019)\end{array}$ & $\begin{array}{c}-0.0863 \\
(0.0266)\end{array}$ & $\begin{array}{c}0.002 \\
(0.0024)\end{array}$ \\
\hline reserves & $\begin{array}{c}-0.0978 \\
(0.05)\end{array}$ & $\begin{array}{l}0.0046 \\
(0.0063)\end{array}$ & $\begin{array}{c}-0.0543 \\
(0.0422)\end{array}$ & $\begin{array}{l}0.0008 \\
(0.0043)\end{array}$ & $\begin{array}{c}-0.1472 \\
(0.0695)\end{array}$ & $\begin{array}{l}0.0064 \\
(0.0099)\end{array}$ & $\begin{array}{c}-0.1327 \\
(0.0604)\end{array}$ & $\begin{array}{l}0.0018 \\
(0.0054)\end{array}$ \\
\hline official transfers & $\begin{array}{c}-0.0417 \\
(0.0309) \\
\end{array}$ & $\begin{array}{c}0.004 \\
(0.0024) \\
\end{array}$ & $\begin{array}{c}-0.0412 \\
(0.0328)\end{array}$ & $\begin{array}{l}0.0035 \\
(0.0029) \\
\end{array}$ & $\begin{array}{c}-0.0347 \\
(0.0377) \\
\end{array}$ & $\begin{array}{c}0.006 \\
(0.0036) \\
\end{array}$ & $\begin{array}{l}-0.036 \\
(0.0415)\end{array}$ & $\begin{array}{l}0.0052 \\
(0.0038) \\
\end{array}$ \\
\hline$\sigma_{\text {mean CAD }}$ & $\begin{array}{l}0.0762 \\
(0.0205)\end{array}$ & $\begin{array}{l}0.0048 \\
(0.0024)\end{array}$ & $\begin{array}{l}0.0207 \\
(0.0206)\end{array}$ & $\begin{array}{l}0.0051 \\
(0.0036)\end{array}$ & $\begin{array}{l}0.0773 \\
(0.0229)\end{array}$ & $\begin{array}{c}0.0045 \\
(0.004)\end{array}$ & $\begin{array}{l}0.0255 \\
(0.0201)\end{array}$ & $\begin{array}{c}0.0022 \\
(0.003)\end{array}$ \\
\hline$\sigma_{\text {reserves }}$ & $\begin{array}{l}0.0146 \\
(0.0759)\end{array}$ & $\begin{array}{l}0.0169 \\
(0.0236)\end{array}$ & $\begin{array}{l}0.0041 \\
(0.0549)\end{array}$ & $\begin{array}{l}0.0044 \\
(0.0097)\end{array}$ & $\begin{array}{l}0.0152 \\
(0.1261)\end{array}$ & $\begin{array}{l}0.0181 \\
(0.1077)\end{array}$ & $\begin{array}{l}0.0019 \\
(0.0862)\end{array}$ & $\begin{array}{l}0.0017 \\
(0.0685)\end{array}$ \\
\hline$\sigma_{\text {official transfers }}$ & $\begin{array}{l}0.0445 \\
(0.0206) \\
\end{array}$ & $\begin{array}{c}0.004 \\
(0.0037)\end{array}$ & $\begin{array}{l}0.0393 \\
(0.0184) \\
\end{array}$ & $\begin{array}{l}0.0022 \\
(0.0021)\end{array}$ & $\begin{array}{l}0.0511 \\
(0.0246) \\
\end{array}$ & $\begin{array}{l}0.0059 \\
(0.0088) \\
\end{array}$ & $\begin{array}{l}0.0531 \\
(0.0248) \\
\end{array}$ & $\begin{array}{l}0.0033 \\
(0.0033) \\
\end{array}$ \\
\hline log-lik. & -254.3004 & 0.4213 & -198.0473 & 0.2795 & -172.2746 & 0.3974 & -135.1179 & 0.2951 \\
\hline
\end{tabular}

Notes: Asymptotic standard errors are given in paranthesis; Results are based on 200 replications; MC errors are based on 20 replications. 
Table 12: Partial Random Coefficients and serial correlation - Simulated Likelihood estimates

\begin{tabular}{lcccccccc}
\hline \hline & $I$ & $M C$ & $I I$ & $M C$ & $I I I$ & $M C$ & $I V$ & $M C$ \\
constant & -0.7171 & 0.048 & -1.1429 & 0.0137 & -0.1609 & 0.0655 & -0.7704 & 0.0259 \\
& $(0.5057)$ & $(0.0335)$ & $(0.3283)$ & $(0.045)$ & $(0.6581)$ & $(0.0389)$ & $(0.3598)$ & $(0.0203)$ \\
mean CAD & -0.1789 & 0.0078 & -0.0773 & 0.0029 & -0.1977 & 0.0087 & -0.0827 & 0.0075 \\
& $(0.0376)$ & $(0.0026)$ & $(0.0197)$ & $(0.0024)$ & $(0.0379)$ & $(0.0074)$ & $(0.0208)$ & $(0.0025)$ \\
reserves & -0.1168 & 0.0069 & -0.0495 & 0.0017 & -0.2254 & 0.0112 & -0.1261 & 0.0034 \\
& $(0.06)$ & $(0.0054)$ & $(0.0369)$ & $(0.0045)$ & $(0.0859)$ & $(0.0068)$ & $(0.0489)$ & $(0.0032)$ \\
concessional debt & -0.0153 & 0.0007 & -0.0113 & 0.0002 & -0.0246 & 0.0009 & -0.0171 & 0.0003 \\
& $(0.0057)$ & $(0.0004)$ & $(0.0038)$ & $(0.0005)$ & $(0.0081)$ & $(0.0006)$ & $(0.0046)$ & $(0.0003)$ \\
terms of trade & -0.0077 & 0.0006 & -0.0032 & 0.0001 & -0.0143 & 0.0007 & -0.0059 & 0.0002 \\
& $(0.0041)$ & $(0.0003)$ & $(0.0024)$ & $(0.0002)$ & $(0.0055)$ & $(0.0004)$ & $(0.0028)$ & $(0.0002)$ \\
\multirow{2}{*}{$\rho$} & 0.5681 & 0.0211 & -0.2753 & 0.0217 & 0.6701 & 0.0171 & -0.2644 & 0.0258 \\
& $(0.0792)$ & $(0.0094)$ & $(0.1135)$ & $(0.0087)$ & $(0.0752)$ & $(0.0156)$ & $(0.1466)$ & $(0.0114)$ \\
\multirow{5}{*}{$\sigma_{\text {mean CAD }}$} & 0.088 & 0.0065 & 0.0346 & 0.0015 & 0.0929 & 0.0083 & 0.0356 & 0.0084 \\
& $(0.0247)$ & $(0.0028)$ & $(0.0151)$ & $(0.0016)$ & $(0.0283)$ & $(0.0054)$ & $(0.0181)$ & $(0.0052)$ \\
\hline log-lik. & -247.4077 & 1.0058 & -201.1559 & 0.3834 & -166.0891 & 0.6224 & -140.8193 & 0.6008 \\
\hline \hline
\end{tabular}

Notes: Asymptotic standard errors are given in parenthesis; Results are based on 200 replications; MC errors are based on 20 replications. 
Table 13: Pooled Treatment Analysis - Likelihood estimates

\begin{tabular}{|c|c|c|c|c|}
\hline & $I$ & $I I$ & $I I I$ & $I V$ \\
\hline constant & $\begin{array}{l}1.7779 \\
(1.0564)\end{array}$ & $\begin{array}{l}1.7377 \\
(1.0686)\end{array}$ & $\begin{array}{l}1.7393 \\
(1.0833)\end{array}$ & $\begin{array}{l}1.8194 \\
(1.0514)\end{array}$ \\
\hline lagged growth & $\begin{array}{l}0.1578 \\
(0.0336)\end{array}$ & $\begin{array}{l}0.1562 \\
(0.0339)\end{array}$ & $\begin{array}{l}0.1628 \\
(0.0345)\end{array}$ & $\begin{array}{l}0.1629 \\
(0.0339)\end{array}$ \\
\hline reversal & $\begin{array}{c}-7.8299 \\
(1.3238)\end{array}$ & $\begin{array}{c}-8.0049 \\
(1.5825)\end{array}$ & $\begin{array}{c}-7.3109 \\
(1.8394)\end{array}$ & $\begin{array}{c}-6.2197 \\
(2.0604)\end{array}$ \\
\hline openness $\times$ reversal & $\begin{array}{l}0.0188 \\
(0.0134)\end{array}$ & $\begin{array}{l}0.0060 \\
(0.0164)\end{array}$ & $\begin{array}{l}0.0297 \\
(0.0158)\end{array}$ & $\begin{array}{l}0.0081 \\
(0.0165)\end{array}$ \\
\hline openness & $\begin{array}{l}0.0027 \\
(0.0055)\end{array}$ & $\begin{array}{l}0.0027 \\
(0.0055)\end{array}$ & $\begin{array}{l}0.0042 \\
(0.0052)\end{array}$ & $\begin{array}{l}0.0045 \\
(0.0053)\end{array}$ \\
\hline mean investment & $\begin{array}{l}0.0811 \\
(0.0235)\end{array}$ & $\begin{array}{l}0.0829 \\
(0.0247)\end{array}$ & $\begin{array}{l}0.0798 \\
(0.0228)\end{array}$ & $\begin{array}{l}0.0745 \\
(0.0242)\end{array}$ \\
\hline initial log GDP & $\begin{array}{c}-0.0217 \\
(0.1467)\end{array}$ & $\begin{array}{c}-0.0508 \\
(0.1542)\end{array}$ & $\begin{array}{c}-0.0795 \\
(0.1472)\end{array}$ & $\begin{array}{c}-0.0922 \\
(0.1468)\end{array}$ \\
\hline constant & $\begin{array}{c}-2.6543 \\
(0.9140)\end{array}$ & $\begin{array}{c}-2.4536 \\
(0.9502)\end{array}$ & $\begin{array}{c}-2.0895 \\
(0.9616)\end{array}$ & $\begin{array}{c}-1.1869 \\
(1.0409)\end{array}$ \\
\hline US real interest rate & $\begin{array}{l}0.1503 \\
(0.0715)\end{array}$ & $\begin{array}{l}0.1260 \\
(0.0808)\end{array}$ & $\begin{array}{l}0.0576 \\
(0.0850)\end{array}$ & $\begin{array}{c}-0.0385 \\
(0.0998)\end{array}$ \\
\hline OECD growth & $\begin{array}{l}0.0478 \\
(0.0817)\end{array}$ & $\begin{array}{l}0.0495 \\
(0.0975)\end{array}$ & $\begin{array}{l}0.0588 \\
(0.1008)\end{array}$ & $\begin{array}{l}0.1160 \\
(0.1193)\end{array}$ \\
\hline openness & $\begin{array}{c}-0.0026 \\
(0.0022)\end{array}$ & $\begin{array}{c}-0.0026 \\
(0.0024)\end{array}$ & $\begin{array}{c}-0.0007 \\
(0.0022)\end{array}$ & $\begin{array}{c}-0.0008 \\
(0.0022)\end{array}$ \\
\hline mean CAD & $\begin{array}{c}-0.0655 \\
(0.0126)\end{array}$ & $\begin{array}{c}-0.0582 \\
(0.0137)\end{array}$ & $\begin{array}{c}-0.0613 \\
(0.0133)\end{array}$ & $\begin{array}{c}-0.0555 \\
(0.0140)\end{array}$ \\
\hline mean investment & $\begin{array}{l}0.0051 \\
(0.0103)\end{array}$ & $\begin{array}{l}0.0095 \\
(0.0119)\end{array}$ & $\begin{array}{l}0.0152 \\
(0.0121)\end{array}$ & $\begin{array}{l}0.0127 \\
(0.0131)\end{array}$ \\
\hline mean growth & $\begin{array}{l}0.0342 \\
(0.0202)\end{array}$ & $\begin{array}{l}0.0290 \\
(0.0230)\end{array}$ & $\begin{array}{l}0.0456 \\
(0.0249)\end{array}$ & $\begin{array}{l}0.0318 \\
(0.0263)\end{array}$ \\
\hline reserves & $\begin{array}{c}-0.0890 \\
(0.0285)\end{array}$ & $\begin{array}{c}-0.0752 \\
(0.0352)\end{array}$ & $\begin{array}{c}-0.1205 \\
(0.0401)\end{array}$ & $\begin{array}{c}-0.1360 \\
(0.0425)\end{array}$ \\
\hline official transfers & $\begin{array}{c}-0.0347 \\
(0.0114)\end{array}$ & $\begin{array}{c}-0.0355 \\
(0.0139)\end{array}$ & $\begin{array}{c}-0.0168 \\
(0.0132)\end{array}$ & $\begin{array}{c}-0.0158 \\
(0.0152)\end{array}$ \\
\hline government consumption & $\begin{array}{l}0.0146 \\
(0.0124)\end{array}$ & $\begin{array}{l}0.0008 \\
(0.0144)\end{array}$ & $\begin{array}{l}0.0288 \\
(0.0132)\end{array}$ & $\begin{array}{l}0.0163 \\
(0.0138)\end{array}$ \\
\hline concessional debt & $\begin{array}{c}-0.0058 \\
(0.0044)\end{array}$ & $\begin{array}{c}-0.0072 \\
(0.0047)\end{array}$ & $\begin{array}{c}-0.0134 \\
(0.0053)\end{array}$ & $\begin{array}{c}-0.0184 \\
(0.0059)\end{array}$ \\
\hline terms of trade & $\begin{array}{c}-0.0018 \\
(0.0017)\end{array}$ & $\begin{array}{c}-0.0017 \\
(0.0019)\end{array}$ & $\begin{array}{c}-0.0060 \\
(0.0022)\end{array}$ & $\begin{array}{c}-0.0049 \\
(0.0023)\end{array}$ \\
\hline interest payments & $\begin{array}{l}0.0138 \\
(0.0294)\end{array}$ & $\begin{array}{c}-0.0024 \\
(0.0348)\end{array}$ & $\begin{array}{l}0.0458 \\
(0.0336)\end{array}$ & $\begin{array}{l}0.0124 \\
(0.0367)\end{array}$ \\
\hline initial log GDP & $\begin{array}{l}0.0768 \\
(0.0897) \\
\end{array}$ & $\begin{array}{l}0.0591 \\
(0.0965) \\
\end{array}$ & $\begin{array}{l}0.0255 \\
(0.1021) \\
\end{array}$ & $\begin{array}{c}-0.0116 \\
(0.1103) \\
\end{array}$ \\
\hline$\rho$ & $\begin{array}{l}0.6716 \\
(0.0715)\end{array}$ & $\begin{array}{l}0.6928 \\
(0.0735)\end{array}$ & $\begin{array}{l}0.4688 \\
(0.1116)\end{array}$ & $\begin{array}{l}0.4712 \\
(0.1452)\end{array}$ \\
\hline$\sigma$ & $\begin{array}{r}5.0094 \\
(0.1406) \\
\end{array}$ & $\begin{array}{l}4.9630 \\
(0.1245) \\
\end{array}$ & $\begin{array}{l}4.8020 \\
(0.1223) \\
\end{array}$ & $\begin{array}{l}4.7891 \\
(0.1103) \\
\end{array}$ \\
\hline log-lik. & -3120.16 & -3050.48 & -3044.06 & -2996.60 \\
\hline
\end{tabular}

Notes: Asymptotic standard errors are given in parenthesis. 
Table 14: Treatment Analysis with serial correlation - SML estimates

\begin{tabular}{|c|c|c|c|c|c|c|c|c|}
\hline & $I$ & $\mathrm{MC}$ & $I I$ & $\mathrm{MC}$ & $I I I$ & $\mathrm{MC}$ & $I V$ & $\mathrm{MC}$ \\
\hline constant & $\begin{array}{l}1.8791 \\
(1.0464)\end{array}$ & $\begin{array}{l}0.0048 \\
(0.0338)\end{array}$ & $\begin{array}{l}1.7995 \\
(1.0684)\end{array}$ & $\begin{array}{l}0.0023 \\
(0.0195)\end{array}$ & $\begin{array}{l}2.1996 \\
(1.0424)\end{array}$ & $\begin{array}{l}0.0084 \\
(0.0284)\end{array}$ & $\begin{array}{l}1.8645 \\
(1.0684)\end{array}$ & $\begin{array}{l}0.0059 \\
(0.0191)\end{array}$ \\
\hline lagged growth & $\begin{array}{l}0.1681 \\
(0.0335)\end{array}$ & $\begin{array}{l}0.0001 \\
(0.0007)\end{array}$ & $\begin{array}{c}0.146 \\
(0.0335)\end{array}$ & $\begin{array}{l}0.0003 \\
(0.0006)\end{array}$ & $\begin{array}{l}0.1657 \\
(0.0339)\end{array}$ & $\begin{array}{l}0.0002 \\
(0.0007)\end{array}$ & $\begin{array}{c}0.159 \\
(0.0329)\end{array}$ & $\begin{array}{l}0.0002 \\
(0.0003)\end{array}$ \\
\hline reversal & $\begin{array}{c}-6.4617 \\
(1.5852)\end{array}$ & $\begin{array}{l}0.0847 \\
(0.0831)\end{array}$ & $\begin{array}{c}-7.5439 \\
(1.5061)\end{array}$ & $\begin{array}{l}0.0295 \\
(0.0487)\end{array}$ & $\begin{array}{c}-2.8536 \\
(1.5972)\end{array}$ & $\begin{array}{l}0.0778 \\
(0.0738)\end{array}$ & $\begin{array}{c}-5.7742 \\
(1.8914)\end{array}$ & $\begin{array}{c}0.0839 \\
(0.068)\end{array}$ \\
\hline reversal $\times$ openness & $\begin{array}{l}0.0132 \\
(0.0136)\end{array}$ & $\begin{array}{l}0.0002 \\
(0.0003)\end{array}$ & $\begin{array}{l}0.0028 \\
(0.0153)\end{array}$ & $\begin{array}{l}0.0001 \\
(0.0003)\end{array}$ & $\begin{array}{c}0.0182 \\
(0.015)\end{array}$ & $\begin{array}{l}0.0001 \\
(0.0006)\end{array}$ & $\begin{array}{l}0.0045 \\
(0.0173)\end{array}$ & $\begin{array}{l}0.0001 \\
(0.0007)\end{array}$ \\
\hline openness & $\begin{array}{c}0.008 \\
(0.0051)\end{array}$ & $\begin{array}{c}0 \\
(0.0001)\end{array}$ & $\begin{array}{l}0.0085 \\
(0.0049)\end{array}$ & $\begin{array}{c}0 \\
(0.0001)\end{array}$ & $\begin{array}{l}0.0077 \\
(0.0049)\end{array}$ & $\begin{array}{c}0 \\
(0.0001)\end{array}$ & $\begin{array}{l}0.0095 \\
(0.0048)\end{array}$ & $\begin{array}{c}0 \\
(0.0001)\end{array}$ \\
\hline investment & $\begin{array}{l}0.0662 \\
(0.0227)\end{array}$ & $\begin{array}{l}0.0001 \\
(0.0005)\end{array}$ & $\begin{array}{l}0.0719 \\
(0.0232)\end{array}$ & $\begin{array}{c}0 \\
(0.0004)\end{array}$ & $\begin{array}{l}0.0581 \\
(0.0236)\end{array}$ & $\begin{array}{l}0.0002 \\
(0.0004)\end{array}$ & $\begin{array}{l}0.0643 \\
(0.0234)\end{array}$ & $\begin{array}{l}0.0002 \\
(0.0003)\end{array}$ \\
\hline log initial GDP & $\begin{array}{c}-0.0606 \\
(0.1464) \\
\end{array}$ & $\begin{array}{l}0.0013 \\
(0.0047) \\
\end{array}$ & $\begin{array}{l}-0.078 \\
(0.1482) \\
\end{array}$ & $\begin{array}{l}0.0004 \\
(0.0024) \\
\end{array}$ & $\begin{array}{c}-0.1505 \\
(0.144) \\
\end{array}$ & $\begin{array}{c}0.001 \\
(0.0036) \\
\end{array}$ & $\begin{array}{c}-0.1138 \\
(0.1468) \\
\end{array}$ & $\begin{array}{l}0.0008 \\
(0.0029) \\
\end{array}$ \\
\hline constant & $\begin{array}{c}-2.6694 \\
(1.1335)\end{array}$ & $\begin{array}{l}0.0147 \\
(0.0599)\end{array}$ & $\begin{array}{l}-2.447 \\
(0.9556)\end{array}$ & $\begin{array}{l}0.0069 \\
(0.0228)\end{array}$ & $\begin{array}{c}-1.2778 \\
(1.2464)\end{array}$ & $\begin{array}{l}0.2461 \\
(0.1719)\end{array}$ & $\begin{array}{c}-1.2813 \\
(1.1229)\end{array}$ & $\begin{array}{l}0.0094 \\
(0.0447)\end{array}$ \\
\hline US real interest & $\begin{array}{l}0.1354 \\
(0.0876)\end{array}$ & $\begin{array}{l}0.0016 \\
(0.0011)\end{array}$ & $\begin{array}{l}0.1311 \\
(0.0853)\end{array}$ & $\begin{array}{l}0.0007 \\
(0.0016)\end{array}$ & $\begin{array}{c}-0.0396 \\
(0.0941)\end{array}$ & $\begin{array}{l}0.0116 \\
(0.0016)\end{array}$ & $\begin{array}{c}-0.0335 \\
(0.0978)\end{array}$ & $\begin{array}{l}0.0024 \\
(0.0015)\end{array}$ \\
\hline OECD growth rate & $\begin{array}{l}0.0358 \\
(0.0989)\end{array}$ & $\begin{array}{l}0.0018 \\
(0.0021)\end{array}$ & $\underset{(0.104)}{0.0615}$ & $\begin{array}{l}0.0015 \\
(0.0026)\end{array}$ & $\begin{array}{l}0.0929 \\
(0.1084)\end{array}$ & $\begin{array}{l}0.0062 \\
(0.0014)\end{array}$ & $\begin{array}{l}0.1327 \\
(0.1137)\end{array}$ & $\begin{array}{l}0.0032 \\
(0.0024)\end{array}$ \\
\hline openness & $\begin{array}{l}-0.003 \\
(0.0033)\end{array}$ & $\begin{array}{l}0.0001 \\
(0.0001)\end{array}$ & $\begin{array}{c}-0.0018 \\
(0.0026)\end{array}$ & $\begin{array}{c}0 \\
(0.0001)\end{array}$ & $\begin{array}{c}-0.0007 \\
(0.0037)\end{array}$ & $\begin{array}{l}0.0004 \\
(0.0004)\end{array}$ & $\begin{array}{c}-0.0005 \\
(0.0027)\end{array}$ & $\begin{array}{l}0 \\
(0)\end{array}$ \\
\hline mean CAD & $\begin{array}{c}-0.0714 \\
(0.0174)\end{array}$ & $\begin{array}{l}0.0005 \\
(0.0005)\end{array}$ & $\begin{array}{c}-0.0611 \\
(0.0154)\end{array}$ & $\begin{array}{l}0.0003 \\
(0.0004)\end{array}$ & $\begin{array}{c}-0.1013 \\
(0.0211)\end{array}$ & $\begin{array}{l}0.0054 \\
(0.0019)\end{array}$ & $\begin{array}{c}-0.0606 \\
(0.0159)\end{array}$ & $\begin{array}{l}0.0005 \\
(0.0003)\end{array}$ \\
\hline mean growth & $\begin{array}{l}0.0132 \\
(0.0155)\end{array}$ & $\begin{array}{l}0.0005 \\
(0.0007)\end{array}$ & $\begin{array}{l}0.0035 \\
(0.0133)\end{array}$ & $\begin{array}{l}0.0002 \\
(0.0004)\end{array}$ & $\underset{(0.016)}{0.0272}$ & $\begin{array}{l}0.0019 \\
(0.0012)\end{array}$ & $\begin{array}{l}0.0075 \\
(0.0155)\end{array}$ & $\begin{array}{l}0.0002 \\
(0.0002)\end{array}$ \\
\hline reserves & $\begin{array}{c}-0.1128 \\
(0.0462)\end{array}$ & $\begin{array}{l}0.0017 \\
(0.0012)\end{array}$ & $\begin{array}{c}-0.0756 \\
(0.0384)\end{array}$ & $\begin{array}{c}0.0003 \\
(0.001)\end{array}$ & $\begin{array}{c}-0.2646 \\
(0.0719)\end{array}$ & $\begin{array}{c}0.016 \\
(0.0057)\end{array}$ & $\begin{array}{c}-0.1379 \\
(0.0516)\end{array}$ & $\begin{array}{l}0.001 \\
(0.001)\end{array}$ \\
\hline mean investment & $\begin{array}{l}-0.003 \\
(0.0288)\end{array}$ & $\begin{array}{l}0.0014 \\
(0.0009)\end{array}$ & $\begin{array}{l}0.0441 \\
(0.0254)\end{array}$ & $\begin{array}{l}0.0004 \\
(0.0008)\end{array}$ & $\begin{array}{l}0.0316 \\
(0.0343)\end{array}$ & $\begin{array}{l}0.0027 \\
(0.0014)\end{array}$ & $\begin{array}{l}0.0504 \\
(0.0312)\end{array}$ & $\begin{array}{l}0.0008 \\
(0.001)\end{array}$ \\
\hline official transfers & $\begin{array}{c}-0.0276 \\
(0.0146)\end{array}$ & $\begin{array}{l}0.0004 \\
(0.0004)\end{array}$ & $\begin{array}{c}-0.0394 \\
(0.0161)\end{array}$ & $\begin{array}{l}0.0003 \\
(0.0017)\end{array}$ & $\begin{array}{l}0.0173 \\
(0.0146)\end{array}$ & $\begin{array}{l}0.0025 \\
(0.0007)\end{array}$ & $\begin{array}{c}-0.0233 \\
(0.0168)\end{array}$ & $\begin{array}{l}0.0004 \\
(0.0004)\end{array}$ \\
\hline government & $\begin{array}{l}0.0156 \\
(0.0164)\end{array}$ & $\begin{array}{l}0.0002 \\
(0.0002)\end{array}$ & $\begin{array}{l}0.0009 \\
(0.0158)\end{array}$ & $\begin{array}{l}0.0002 \\
(0.0004)\end{array}$ & $\begin{array}{l}0.0162 \\
(0.0161)\end{array}$ & $\begin{array}{l}0.0021 \\
(0.0006)\end{array}$ & $\begin{array}{l}0.0181 \\
(0.0154)\end{array}$ & $\begin{array}{l}0.0004 \\
(0.0001)\end{array}$ \\
\hline concessional debt & $\begin{array}{c}-0.0063 \\
(0.0058)\end{array}$ & $\begin{array}{l}0.0001 \\
(0.0002)\end{array}$ & $\begin{array}{c}-0.0079 \\
(0.0049)\end{array}$ & $\begin{array}{c}0 \\
(0.0001)\end{array}$ & $\begin{array}{c}-0.0263 \\
(0.0084)\end{array}$ & $\begin{array}{l}0.0019 \\
(0.0009)\end{array}$ & $\begin{array}{c}-0.0194 \\
(0.0066)\end{array}$ & $\begin{array}{l}0.0002 \\
(0.0002)\end{array}$ \\
\hline terms of trade & $\begin{array}{c}-0.0029 \\
(0.0027)\end{array}$ & $\begin{array}{l}0.0001 \\
(0.0001)\end{array}$ & $\begin{array}{c}-0.0018 \\
(0.0021)\end{array}$ & $\begin{array}{c}0 \\
(0)\end{array}$ & $\begin{array}{c}-0.0144 \\
(0.004)\end{array}$ & $\begin{array}{l}0.0008 \\
(0.0004)\end{array}$ & $\begin{array}{c}-0.0047 \\
(0.0027)\end{array}$ & $\begin{array}{c}0 \\
(0.0001)\end{array}$ \\
\hline interest payments & $\begin{array}{l}0.0123 \\
(0.0395)\end{array}$ & $\begin{array}{l}0.0005 \\
(0.0007)\end{array}$ & $\begin{array}{c}-0.0025 \\
(0.036)\end{array}$ & $\begin{array}{c}0.0002 \\
(0.001)\end{array}$ & $\begin{array}{l}0.0812 \\
(0.0397)\end{array}$ & $\begin{array}{l}0.0044 \\
(0.0007)\end{array}$ & $\begin{array}{l}0.0102 \\
(0.0398)\end{array}$ & $\begin{array}{l}0.0006 \\
(0.0008)\end{array}$ \\
\hline $\log$ initial GDP & $\begin{array}{l}0.1038 \\
(0.1224) \\
\end{array}$ & $\begin{array}{l}0.0022 \\
(0.0103) \\
\end{array}$ & $\begin{array}{l}0.0494 \\
(0.0981) \\
\end{array}$ & $\begin{array}{l}0.0006 \\
(0.0035) \\
\end{array}$ & $\begin{array}{c}0.0616 \\
(0.135) \\
\end{array}$ & $\begin{array}{l}0.0199 \\
(0.0142) \\
\end{array}$ & $\begin{array}{c}-0.0189 \\
(0.1167)\end{array}$ & $\begin{array}{l}0.0008 \\
(0.0034) \\
\end{array}$ \\
\hline$\psi$ & $\begin{array}{l}0.3351 \\
(0.1029)\end{array}$ & $\begin{array}{c}0.011 \\
(0.0093)\end{array}$ & $\begin{array}{c}-0.2106 \\
(0.096)\end{array}$ & $\begin{array}{l}0.0067 \\
(0.0064)\end{array}$ & $\begin{array}{l}0.7222 \\
(0.0733)\end{array}$ & $\begin{array}{c}0.023 \\
(0.0073)\end{array}$ & $\begin{array}{c}-0.2952 \\
(0.12)\end{array}$ & $\begin{array}{l}0.0177 \\
(0.0055)\end{array}$ \\
\hline$\rho$ & $\begin{array}{l}0.6031 \\
(0.1136)\end{array}$ & $\begin{array}{l}0.0064 \\
(0.0103)\end{array}$ & $\begin{array}{l}0.6826 \\
(0.0832)\end{array}$ & $\begin{array}{l}0.0019 \\
(0.0064)\end{array}$ & $\begin{array}{l}0.0402 \\
(0.1424)\end{array}$ & $\begin{array}{l}0.0132 \\
(0.0136)\end{array}$ & $\begin{array}{c}0.473 \\
(0.1233)\end{array}$ & $\begin{array}{c}0.006 \\
(0.0038)\end{array}$ \\
\hline$\sigma$ & $\begin{array}{l}4.9115 \\
(0.1456) \\
\end{array}$ & $\begin{array}{l}0.0064 \\
(0.0049) \\
\end{array}$ & $\begin{array}{l}4.9389 \\
(0.1292) \\
\end{array}$ & $\begin{array}{l}0.0022 \\
(0.0038) \\
\end{array}$ & $\begin{array}{l}4.7022 \\
(0.1071) \\
\end{array}$ & $\begin{array}{l}0.0004 \\
(0.0034) \\
\end{array}$ & $\begin{array}{l}4.7761 \\
(0.1103) \\
\end{array}$ & $\begin{array}{l}0.0027 \\
(0.0037) \\
\end{array}$ \\
\hline log-lik. & -3109.8 & 0.23 & -3046.3 & 0.1 & -3026.1 & 0.7 & -2992.3 & 0.3 \\
\hline
\end{tabular}

Notes: Asymptotic standard errors are given in parenthesis; Results are based on 200 replications; MC errors are based on 20 replications. 
Table 15: Treatment analysis with partial heterogeneity and serial correlation- SML estimates

\begin{tabular}{|c|c|c|c|c|c|c|c|c|}
\hline & $I$ & $\mathrm{MC}$ & $I I$ & $\mathrm{MC}$ & $I I I$ & $\mathrm{MC}$ & $I V$ & $\mathrm{MC}$ \\
\hline constant & $\begin{array}{c}2.218 \\
(1.1192)\end{array}$ & $\begin{array}{c}0.0341 \\
(0.045)\end{array}$ & $\begin{array}{l}1.9187 \\
(1.1382)\end{array}$ & $\begin{array}{l}0.0336 \\
(0.0516)\end{array}$ & $\begin{array}{l}2.0842 \\
(1.0622)\end{array}$ & $\begin{array}{l}0.0364 \\
(0.0171)\end{array}$ & $\begin{array}{l}1.8532 \\
(1.0752)\end{array}$ & $\begin{array}{l}0.1084 \\
(0.1879)\end{array}$ \\
\hline lagged growth & $\begin{array}{c}0.2207 \\
(0.044)\end{array}$ & $\begin{array}{l}0.0054 \\
(0.0018)\end{array}$ & $\begin{array}{l}0.1779 \\
(0.0481)\end{array}$ & $\begin{array}{c}0.0038 \\
(0.002)\end{array}$ & $\begin{array}{l}0.2213 \\
(0.0434)\end{array}$ & $\begin{array}{l}0.0063 \\
(0.0021)\end{array}$ & $\begin{array}{l}0.2043 \\
(0.0441)\end{array}$ & $\begin{array}{l}0.0069 \\
(0.0021)\end{array}$ \\
\hline reversal & $\begin{array}{c}-2.4942 \\
(1.244)\end{array}$ & $\begin{array}{l}0.0529 \\
(0.0648)\end{array}$ & $\begin{array}{c}-7.1816 \\
(1.5583)\end{array}$ & $\begin{array}{c}0.0365 \\
(0.098)\end{array}$ & $\begin{array}{c}-3.5926 \\
(1.4117)\end{array}$ & $\begin{array}{l}0.0699 \\
(0.0748)\end{array}$ & $\begin{array}{c}-5.3029 \\
(1.934)\end{array}$ & $\begin{array}{c}0.6907 \\
(0.26)\end{array}$ \\
\hline reversal $\times$ openness & $\begin{array}{l}0.0093 \\
(0.0138)\end{array}$ & $\begin{array}{l}0.0002 \\
(0.0006)\end{array}$ & $\begin{array}{l}0.0024 \\
(0.0153)\end{array}$ & $\begin{array}{l}0.0002 \\
(0.0006)\end{array}$ & $\begin{array}{l}0.0186 \\
(0.0145)\end{array}$ & $\begin{array}{l}0.0003 \\
(0.0007)\end{array}$ & $\begin{array}{l}0.0011 \\
(0.0164)\end{array}$ & $\begin{array}{c}0.001 \\
(0.0013)\end{array}$ \\
\hline openness & $\begin{array}{l}0.0088 \\
(0.0056)\end{array}$ & $\begin{array}{l}0.0003 \\
(0.0002)\end{array}$ & $\begin{array}{l}0.0103 \\
(0.0056)\end{array}$ & $\begin{array}{l}0.0002 \\
(0.0001)\end{array}$ & $\begin{array}{l}0.0084 \\
(0.0055)\end{array}$ & $\begin{array}{l}0.0002 \\
(0.0002)\end{array}$ & $\begin{array}{l}0.0106 \\
(0.0053)\end{array}$ & $\begin{array}{l}0.0003 \\
(0.0002)\end{array}$ \\
\hline investment & $\begin{array}{l}0.0245 \\
(0.0254)\end{array}$ & $\begin{array}{l}0.0017 \\
(0.0009)\end{array}$ & $\begin{array}{l}0.0373 \\
(0.0259)\end{array}$ & $\begin{array}{l}0.0011 \\
(0.0005)\end{array}$ & $\begin{array}{l}0.0297 \\
(0.0254)\end{array}$ & $\begin{array}{l}0.0011 \\
(0.0008)\end{array}$ & $\begin{array}{l}0.0308 \\
(0.0252)\end{array}$ & $\begin{array}{c}0.002 \\
(0.0011)\end{array}$ \\
\hline $\log$ initial GDP & $\begin{array}{c}-0.0881 \\
(0.1584)\end{array}$ & $\begin{array}{l}0.0068 \\
(0.0052)\end{array}$ & $\begin{array}{c}-0.0407 \\
(0.1601)\end{array}$ & $\begin{array}{l}0.0059 \\
(0.0069) \\
\end{array}$ & $\begin{array}{c}-0.0873 \\
(0.1494)\end{array}$ & $\begin{array}{l}0.0061 \\
(0.0033)\end{array}$ & $\begin{array}{c}-0.0579 \\
(0.1543)\end{array}$ & $\begin{array}{l}0.0155 \\
(0.0161) \\
\end{array}$ \\
\hline constant & $\begin{array}{c}-0.9073 \\
(0.6089)\end{array}$ & $\begin{array}{l}0.0365 \\
(0.0472)\end{array}$ & $\begin{array}{c}-1.1924 \\
(0.407)\end{array}$ & $\begin{array}{l}0.0087 \\
(0.0309)\end{array}$ & $\begin{array}{c}-0.7598 \\
(0.7153)\end{array}$ & $\begin{array}{l}0.0556 \\
(0.0383)\end{array}$ & $\begin{array}{c}-0.8831 \\
(0.4168)\end{array}$ & $\begin{array}{l}0.4826 \\
(0.0488)\end{array}$ \\
\hline mean CAD & $\begin{array}{c}-0.1715 \\
(0.0349)\end{array}$ & $\begin{array}{l}0.0051 \\
(0.0025)\end{array}$ & $\begin{array}{c}-0.0609 \\
(0.0217)\end{array}$ & $\begin{array}{l}0.0015 \\
(0.0021)\end{array}$ & $\begin{array}{l}-0.17 \\
(0.0378)\end{array}$ & $\begin{array}{l}0.0048 \\
(0.0019)\end{array}$ & $\begin{array}{c}-0.0726 \\
(0.0229)\end{array}$ & $\begin{array}{l}0.0101 \\
(0.002)\end{array}$ \\
\hline investment & $\begin{array}{l}0.0121 \\
(0.0175)\end{array}$ & $\begin{array}{c}0.0011 \\
(0.001)\end{array}$ & $\begin{array}{l}0.0135 \\
(0.0107)\end{array}$ & $\begin{array}{l}0.0002 \\
(0.0007)\end{array}$ & $\begin{array}{l}0.0388 \\
(0.0202)\end{array}$ & $\begin{array}{l}0.0014 \\
(0.0013)\end{array}$ & $\begin{array}{l}0.0197 \\
(0.0125)\end{array}$ & $\begin{array}{c}0.0035 \\
(0.002)\end{array}$ \\
\hline reserves & $\begin{array}{c}-0.1349 \\
(0.0564)\end{array}$ & $\begin{array}{l}0.0059 \\
(0.0032)\end{array}$ & $\begin{array}{c}-0.0641 \\
(0.0368)\end{array}$ & $\begin{array}{l}0.0007 \\
(0.0038)\end{array}$ & $\begin{array}{c}-0.2617 \\
(0.0797)\end{array}$ & $\begin{array}{l}0.0091 \\
(0.0032)\end{array}$ & $\begin{array}{c}-0.1495 \\
(0.0518)\end{array}$ & $\begin{array}{l}0.0118 \\
(0.0054)\end{array}$ \\
\hline concessional debt & $\begin{array}{l}-0.016 \\
(0.0053)\end{array}$ & $\begin{array}{l}0.0004 \\
(0.0003)\end{array}$ & $\begin{array}{c}-0.0138 \\
(0.004)\end{array}$ & $\begin{array}{l}0.0001 \\
(0.0004)\end{array}$ & $\begin{array}{c}-0.0259 \\
(0.0073)\end{array}$ & $\begin{array}{l}0.0008 \\
(0.0004)\end{array}$ & $\begin{array}{c}-0.0216 \\
(0.0051)\end{array}$ & $\begin{array}{l}0.0017 \\
(0.0003)\end{array}$ \\
\hline terms of trade & $\begin{array}{c}-0.0073 \\
(0.0039)\end{array}$ & $\begin{array}{l}0.0003 \\
(0.0002) \\
\end{array}$ & $\begin{array}{c}-0.0028 \\
(0.0024)\end{array}$ & $\begin{array}{l}0.0001 \\
(0.0001) \\
\end{array}$ & $\begin{array}{c}-0.0142 \\
(0.0053)\end{array}$ & $\begin{array}{l}0.0006 \\
(0.0002) \\
\end{array}$ & $\begin{array}{c}-0.0065 \\
(0.0028)\end{array}$ & $\begin{array}{l}0.0039 \\
(0.0003) \\
\end{array}$ \\
\hline$\psi$ & $\begin{array}{l}0.5723 \\
(0.0782)\end{array}$ & $\begin{array}{l}0.0124 \\
(0.0067)\end{array}$ & $\begin{array}{l}-0.251 \\
(0.0939)\end{array}$ & $\begin{array}{l}0.0073 \\
(0.0064)\end{array}$ & $\begin{array}{l}0.6698 \\
(0.0855)\end{array}$ & $\begin{array}{l}0.0139 \\
(0.0048)\end{array}$ & $\begin{array}{c}-0.2366 \\
(0.1317)\end{array}$ & $\begin{array}{l}0.1214 \\
(0.0348)\end{array}$ \\
\hline$\rho$ & $\begin{array}{l}0.1697 \\
(0.0897)\end{array}$ & $\begin{array}{l}0.0074 \\
(0.0072)\end{array}$ & $\begin{array}{l}0.6669 \\
(0.0942)\end{array}$ & $\begin{array}{l}0.0026 \\
(0.0082)\end{array}$ & $\begin{array}{l}0.1966 \\
(0.0953)\end{array}$ & $\begin{array}{l}0.0123 \\
(0.0052)\end{array}$ & $\begin{array}{c}0.4502 \\
(0.14)\end{array}$ & $\begin{array}{l}0.0778 \\
(0.0383)\end{array}$ \\
\hline$\sigma$ & $\begin{array}{l}4.5328 \\
(0.1017) \\
\end{array}$ & $\begin{array}{l}0.0024 \\
(0.0042) \\
\end{array}$ & $\begin{array}{l}4.7389 \\
(0.1306) \\
\end{array}$ & $\begin{array}{l}0.0026 \\
(0.0052) \\
\end{array}$ & $\begin{array}{l}4.5287 \\
(0.1026) \\
\end{array}$ & $\begin{array}{l}0.0021 \\
(0.0065) \\
\end{array}$ & $\begin{array}{l}4.5886 \\
(0.1117) \\
\end{array}$ & $\begin{array}{c}0.02 \\
(0.0052) \\
\end{array}$ \\
\hline$\sigma_{\text {lagged growth }}$ & $\begin{array}{l}0.1899 \\
(0.0321)\end{array}$ & $\begin{array}{l}0.0044 \\
(0.0023)\end{array}$ & $\begin{array}{l}0.1874 \\
(0.0373)\end{array}$ & $\begin{array}{l}0.0029 \\
(0.0026)\end{array}$ & $\begin{array}{c}0.1864 \\
(0.032)\end{array}$ & $\begin{array}{l}0.0049 \\
(0.0023)\end{array}$ & $\begin{array}{l}0.1864 \\
(0.0315)\end{array}$ & $\begin{array}{c}0.0034 \\
(0.003)\end{array}$ \\
\hline$\sigma_{\text {mean } \mathrm{CAD}}$ & $\begin{array}{l}0.0854 \\
(0.0257)\end{array}$ & $\begin{array}{l}0.0042 \\
(0.0037)\end{array}$ & $\begin{array}{c}0.028 \\
(0.0151)\end{array}$ & $\begin{array}{l}0.0011 \\
(0.0021)\end{array}$ & $\begin{array}{l}0.0871 \\
(0.0276)\end{array}$ & $\begin{array}{l}0.0066 \\
(0.0025)\end{array}$ & $\begin{array}{l}0.0318 \\
(0.0161)\end{array}$ & $\begin{array}{c}0.007 \\
(0.0018)\end{array}$ \\
\hline log-lik. & -3084.6 & 0.6 & -3033.6 & 0.4 & -3001.4 & 0.7 & -2976.6 & 0.4 \\
\hline
\end{tabular}

Notes: Asymptotic standard errors are given in parenthesis; Results are based on 200 replications; MC errors are based on 20 replications. 
Table 16: Classification Analysis for Reversals with Bayesian Probit Estimates

\begin{tabular}{|c|c|c|c|c|c|c|c|c|c|c|c|c|c|}
\hline & & \multicolumn{3}{|c|}{$I$} & \multicolumn{3}{|c|}{$I I$} & \multicolumn{3}{|c|}{$I I I$} & \multicolumn{3}{|c|}{$I V$} \\
\hline & & 0 & 1 & $\sum$ & 0 & 1 & $\sum$ & 0 & 1 & $\sum$ & 0 & 1 & $\sum$ \\
\hline \multirow{4}{*}{ pooled } & 0 & 848 & 15 & 863 & 901 & 2 & 903 & 890 & 6 & 896 & 919 & 3 & 921 \\
\hline & 1 & 90 & 10 & 100 & 59 & 1 & 60 & 65 & 2 & 67 & 40 & 1 & 41 \\
\hline & $\sum$ & 938 & 25 & 963 & 960 & 3 & 963 & 955 & 8 & 963 & 959 & 4 & 963 \\
\hline & & 0 & 1 & $\sum$ & 0 & 1 & $\sum$ & 0 & 1 & $\sum$ & 0 & 1 & $\sum$ \\
\hline \multirow{4}{*}{ serial } & 0 & 852 & 11 & 863 & 902 & 1 & 903 & 889 & 7 & 896 & 922 & 0 & 922 \\
\hline & 1 & 95 & 5 & 100 & 59 & 1 & 60 & 64 & 3 & 67 & 41 & 0 & 41 \\
\hline & $\sum$ & 947 & 16 & 963 & 961 & 2 & 963 & 953 & 10 & 963 & 963 & 0 & 963 \\
\hline & & 0 & 1 & $\sum$ & 0 & 1 & $\sum$ & 0 & 1 & $\sum$ & 0 & 1 & $\sum$ \\
\hline \multirow{4}{*}{ heterogeneity } & 0 & 862 & 1 & 863 & 903 & 0 & 903 & 896 & 0 & 896 & 922 & 0 & 922 \\
\hline & 1 & 73 & 27 & 100 & 54 & 6 & 60 & 56 & 11 & 67 & 40 & 1 & 41 \\
\hline & $\sum$ & 935 & 28 & 963 & 957 & 6 & 963 & 952 & 11 & 963 & 962 & 1 & 963 \\
\hline & & 0 & 1 & $\sum$ & 0 & 1 & $\sum$ & 0 & 1 & $\sum$ & 0 & 1 & $\sum$ \\
\hline \multirow{3}{*}{ het.+serial } & 0 & 856 & 7 & 863 & 903 & 0 & 903 & 892 & 4 & 896 & 922 & 0 & 922 \\
\hline & 1 & 76 & 24 & 100 & 58 & 2 & 60 & 52 & 15 & 67 & 39 & 2 & 41 \\
\hline & $\sum$ & 932 & 31 & 963 & 961 & 2 & 963 & 944 & 19 & 963 & 961 & 2 & 963 \\
\hline
\end{tabular}

Notes: The columns refer to the identified state. whereas the rows give the observed state. 
Figure 1: Heterogeneity within the Probit Coefficients
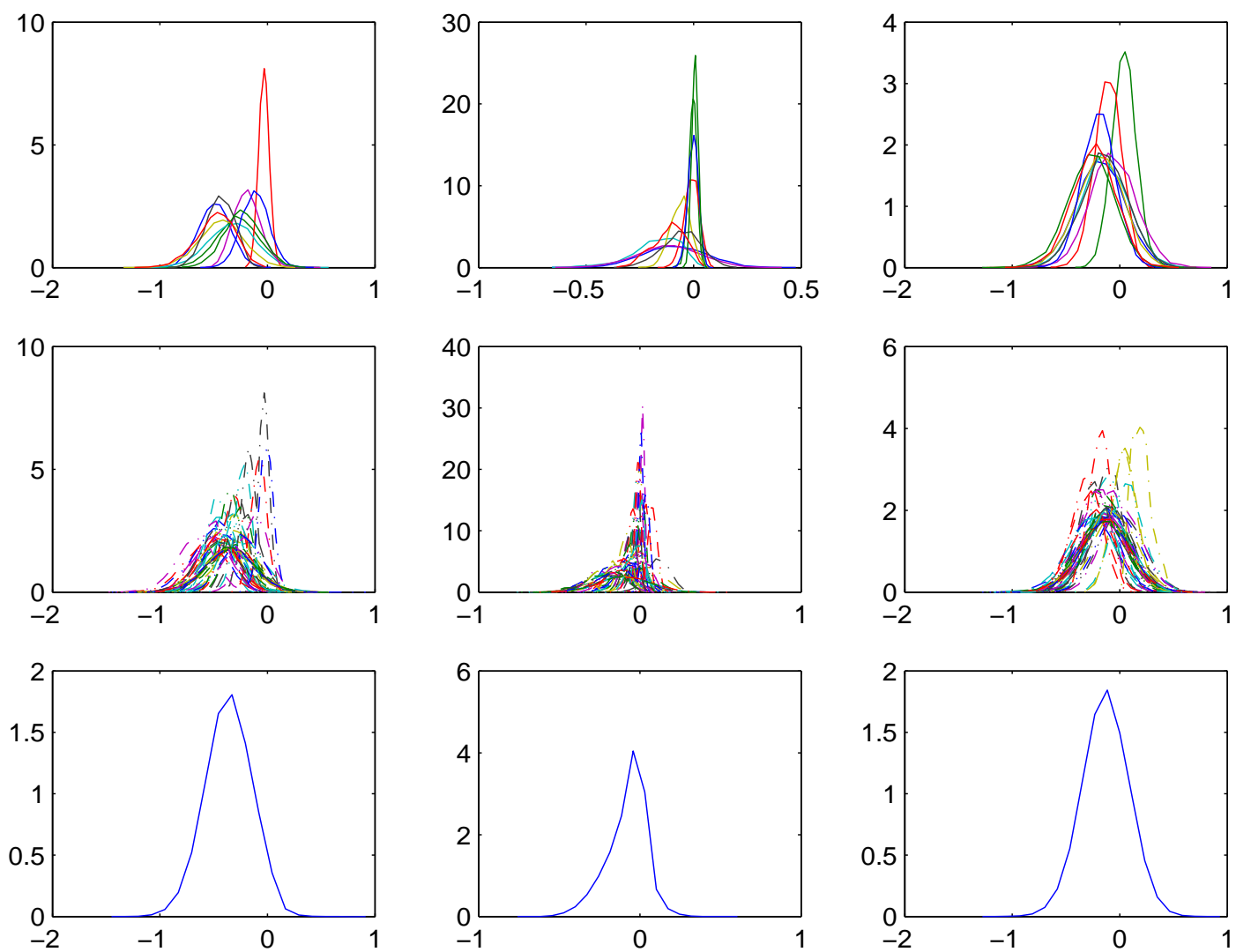

Notes: Heterogeneity for reversal scheme I: left - histograms of the sampled country specific coefficient for variable mean CAD; middle - histograms of the sampled country specific coefficient for variable reserves histograms of the sampled country specific coefficient for variable official transfers; The upper panel gives the histograms for the countries listed in the legend; the middle shows all countries; the lower panel shows the histogram the average over all countries of sampled coefficients. 